Arkivoc

Free to Authors and Readers
A Platinum Open Access Journal for Organic Chemistry

Paper

DOAJ Seal
Arkivoc 2022, part iv, 24-45

\title{
Some new 2,8-disubstituted-1,7-dicyano-3,9-diazaperylenes
}

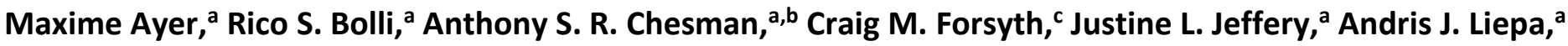 \\ Karolina M. Morawska, ${ }^{\mathrm{a}}$ Théo Ozga, ${ }^{\mathrm{a}}$ and Craig L. Francis ${ }^{\mathrm{a} *}$ \\ ${ }^{a}$ CSIRO Manufacturing, Jerry Price Laboratory, Clayton, VIC 3168, Australia \\ ${ }^{b}$ Melbourne Centre for Nanofabrication, Clayton, VIC 3168, Australia \\ ' School of Chemistry, Monash University, Clayton, VIC 3800, Australia \\ Email: craig.francis@csiro.au
}

Received 10-11-2021

Accepted Manuscript 11-16-2021

Published on line $12-10-2021$

\section{Abstract}

Concise synthetic protocols for a range of new 2,8-disubstituted-1,7-dicyano-3,9-diazaperylenes, starting from commercially available 1,5-diaminoanthraquinone, have been developed, which enable the introduction of various tertiary-amino, substituted-ethynyl, and aryl groups at the C2 and C8 positions, as well as incorporation of aryl-amino groups at the C4 and C10 positions, of the rare 3,9-diazaperylene system. This methodology should enable tuning of physical and optoelectronic properties and may find use in the discovery of new materials for organic photovoltaic devices or other organic electronic applications.

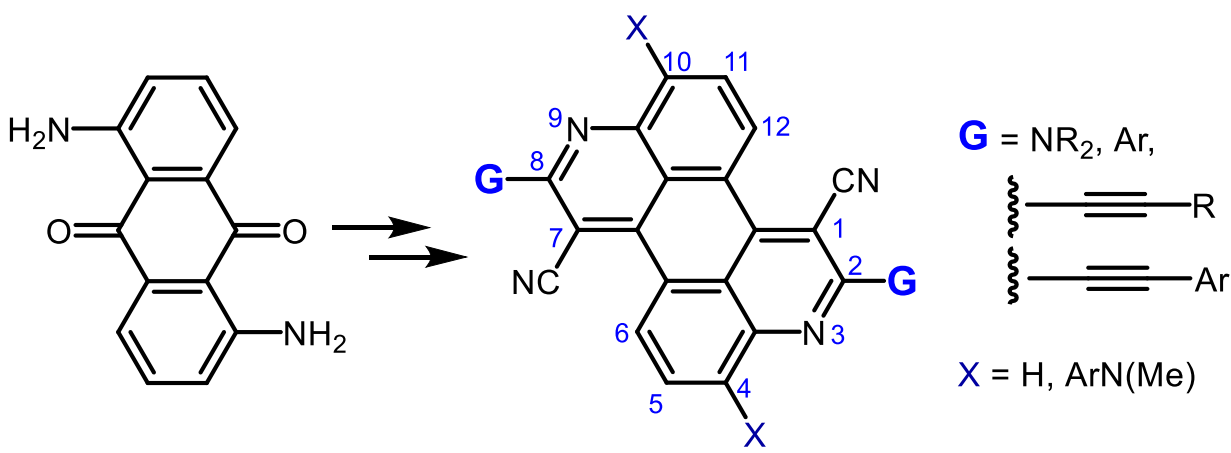

Keywords: Diazaperylene, synthesis, Sonogashira, Stille, UV-visible, n-type 


\section{Introduction}

It is widely accepted that fossil fuels give rise to serious environmental problems and there is a pressing need to develop renewable energy sources. The development of photovoltaic devices (PVs), which transform practically inexhaustible solar energy into electricity, is one of the most promising long-term solutions for clean, renewable energy. Organic photovoltaic devices (OPVs) using soluble small molecules have emerged as promising candidates for OPV applications. Small molecules have advantages including well-defined molecular structures, consistency in synthesis, ease of purification, and a tendency to exhibit high charge mobility due to their long-range order. ${ }^{1-4}$

A majority of OPV research has been focused on the development of electron donor, or so called " $\mathrm{p}$-type", semiconductors; much less attention has been devoted to electron acceptor, or " $\mathrm{n}$-type", materials., 3 Fullerenes, among the commonly used acceptor materials, suffer from high cost and other shortcomings, which has encouraged efforts towards the discovery and development of new, high-performance n-type small molecules for OPVs. New materials would assist the development of structure-property relationships and add versatility to the selection of donor/acceptor pairs to maximize, for example, absorption across the solar spectrum, or allow the use of materials with energy levels not suited to fullerenes. ${ }^{6}$

A feature generally regarded as desirable for stable, electron-accepting (n-type) small molecules is electron deficiency, to preferentially lower the energy of the LUMO. This can be achieved by strategies such as the substitution of the $\pi$-system with $\pi$-acceptors such as cyano and carbonyl groups, which also increases the conjugation length, or the substitution of atoms in an extended $\pi$-system with more electronegative atoms, e.g. replacing carbocyclic rings with certain nitrogen heterocycles. ${ }^{5}$

To enable fabrication of OPV devices via solution processing, the incorporation of long alkyl side chains for increased solubility in organic solvents has been a frequently applied strategy. However, the nature of the side chains also affects the intermolecular interaction of the molecules and charge transport properties. In particular, the side chains affect the morphology of films and therefore the performance of OPV devices. An increased content of insulating alkyl side chains relative to the conjugated core of the molecule may result in deterioration in charge transport, so a balanced choice of suitable solubilizing groups at appropriate sites is crucial for fine-tuning the structure-properties relationship. ${ }^{1}$

Classes of non-fullerene $n$-type small molecules which exemplify the successful application of the above strategies include the rylene diimides, dicyanoimidazoles, diketopyrrolopyrroles bearing electron withdrawing groups, and fluoro- and cyanopentacenes. Ample discussion of these classes of molecules can be found in several reviews. ${ }^{1,5,6}$

The use of industrial dyes and pigments as starting points for discovery of organic semiconductors is attractive in several ways. These types of molecules possess attributes such as strong light absorption and photochemical stability, and are usually sourced from robust, large-scale synthetic protocols. ${ }^{4}$ Indeed, some of the classes of $n$-type small molecules listed above were first used industrially as dyes and pigments; most notably the rylene diimides and diketopyrrolopyrroles.

In light of all of the above, we noted two isolated reports by Tatke and Seshadri from the mid-1980s describing the preparation of 2,8-di(morpholin-4-yl)-1,7-dicyano-3,9-diazaperylene 3a (from the dye precursor 1,5-diaminoanthraquinone 1$)^{7}$ and its substitution with 4-chloroaniline ${ }^{8}$ and more recent reports from $Y i$ Liu and co-workers which described synthesis of 2,8-dialkyl-, 2,8-dialkoxy-, and 2,8-dialkylthio-1,7-diaryl3,9-diazaperylenes and their conversion to corresponding diazacoronenes for incorporation into conjugated polymers for organic photovoltaic device studies ${ }^{9}$ and as potential colorimetric and fluorescence proton sensors. ${ }^{10}$ Schneider and Perepichka ${ }^{11}$ described synthesis of simpler 3,9-diazaperylenes, accompanied by 
isomeric 1,8-diazabenzo[e]pyrene side products, and Bock and co-workers ${ }^{12}$ prepared extended heteroarenes containing the 3,9-diazaperylene system with additional ring fusions; both of these studies were scouting for potential $n$-type $\pi$-functional materials. Further, derivatives of the related 1,7-diazaperylenes have been claimed as organic semiconductor materials for thin film transistors. ${ }^{13}$

In our view, the rare 3,9-diazaperylene ring system, particularly with electron withdrawing 1,7-dicyano substitution, appeared to satisfy many of the requirements for a n-type organic semiconductor material. In addition, scope existed for variation of the substituents at the 2- and 8-positions which could be used for tuning both solubility and electronic properties.

This paper describes synthetic methods established during an exploratory chemistry effort towards discovery of new n-type materials that led to several new 2,8-disubstituted-1,7-dicyano-3,9-diazaperylenes.

\section{Results and Discussion}

The synthetic route to the 2,8-bis(dialkylamino) compounds 3 was essentially that of Tatke and Seshadri ${ }^{7}$ (Scheme 1). The cyanoacetamides $\mathbf{2 b}$ - $\mathbf{d}$ were conveniently prepared from ethyl cyanoacetate and the appropriate secondary amine by modification of literature procedures. ${ }^{14-17}$ Interestingly, in our hands, the use of microwave heating afforded quicker and cleaner reactions than conventional heating.<smiles>Nc1cccc2c1C(=O)c1cccc(N)c1C2=O</smiles>

1

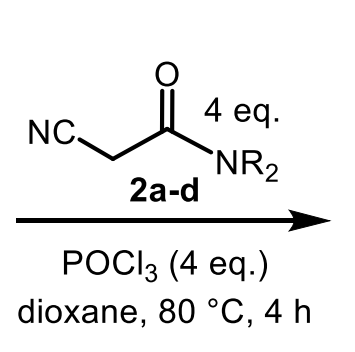

$$
\begin{aligned}
& \text { a } \mathrm{R}_{2} \mathrm{~N}=\text { morpholin-4-yl } \\
& \text { b } \mathrm{R}_{2} \mathrm{~N}=\text { piperidin-1-yl } \\
& \text { c } \mathrm{R}=\mathrm{Et} \\
& \text { d } \mathrm{R}={ }^{\mathrm{n}} \mathrm{Pr}
\end{aligned}
$$

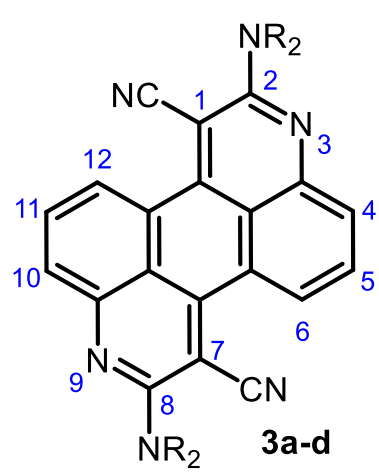

3a $\left(\right.$ lit. $\left.^{7} 84 \%\right)$

3b $(36 \%)$

3c $(22 \%)$

3d $(12 \%)$

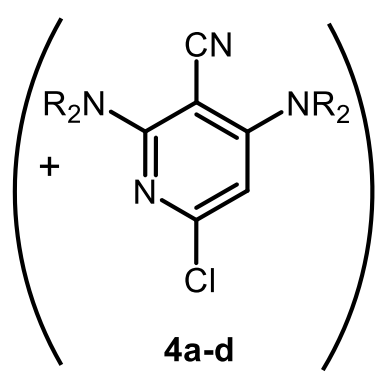

4a (lit. $^{7}$ yield not reported)

4b $(35 \%)$

4c $(25 \%)$

4d $(41 \%)$

\section{Scheme 1}

Reactions of 1,5-diaminoanthraquinone 1 with the Vilsmeier reagents prepared from cyanoacetamides $\mathbf{2 b}$-d and phosphoryl chloride in dioxane at $80{ }^{\circ} \mathrm{C}$ afforded modest yields of the desired 1,7-dicyano-

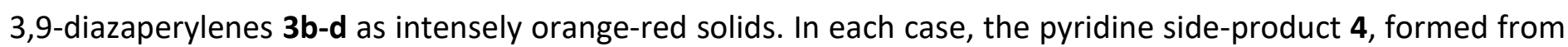
the known ${ }^{14}$ self-condensation of cyanoacetamides under the influence of phosphorus oxychloride, was also isolated during chromatographic purification.

The crystal structure of bis-diethylamino derivative $3 \mathrm{c}$ is shown in Figures 1-3. 


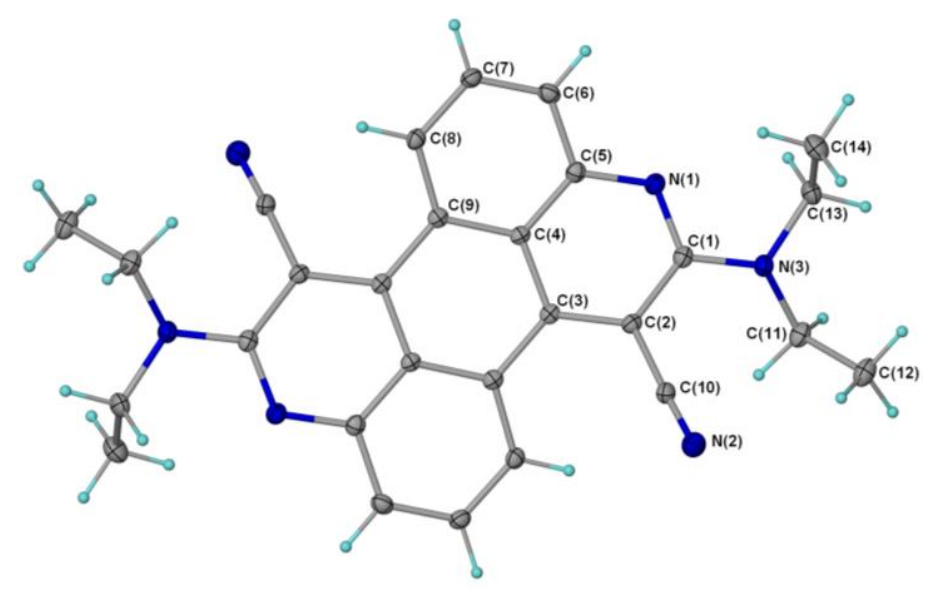

Figure 1. Crystal structure of the bis-diethylamino derivative $3 \mathrm{c}$ with $30 \%$ ellipsoids and hydrogen atoms as spheres of arbitrary size.
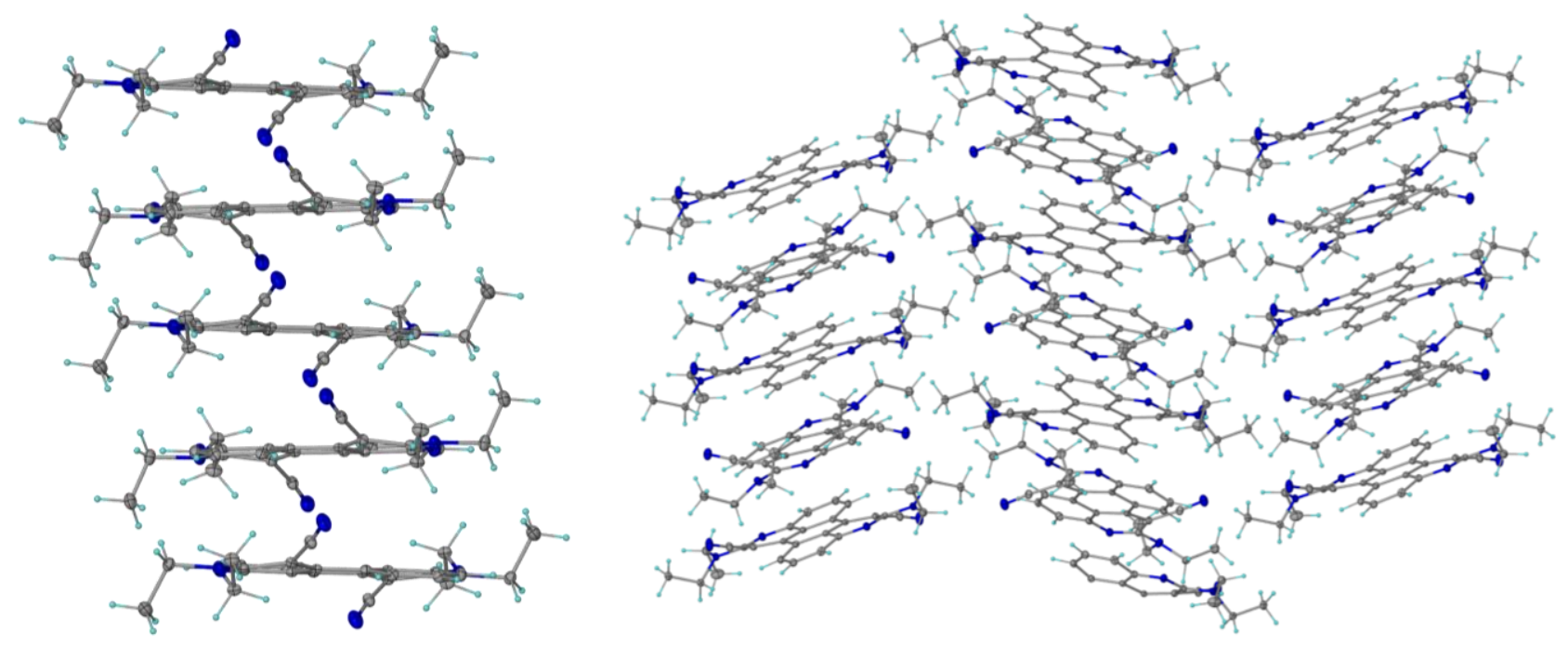

Figure 2. Packing of successive molecules of bis-diethylamino derivative $3 c$ due to $\pi-\pi$ stacking of arenes.

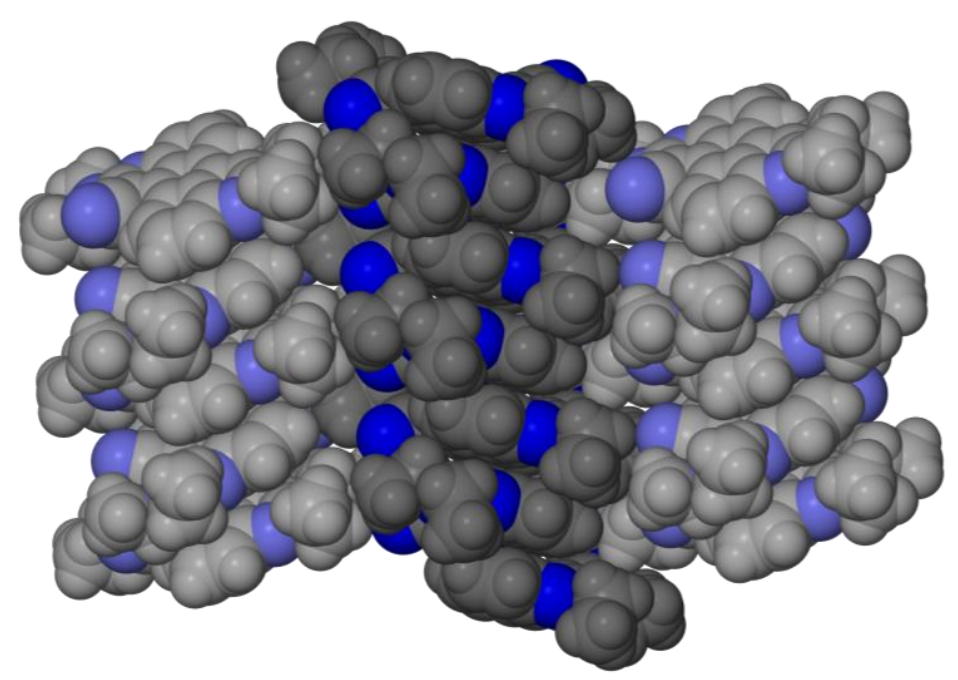

Figure 3. Space filling representations of molecular packing of molecules of bis-diethylamino derivative $\mathbf{3 c}$. 
The crystal structure of compound $3 \mathrm{c}$ shows $\pi-\pi$ stacking of the aromatic ring systems of the individual molecules (Figures 2 \& 3), with the closest stacking distance (interplanar spacing) of $3.45 \AA$, which is approaching the proximity required for strong electronic coupling between molecules, a necessary criterion for ensuring the high charge mobility that is essential for good semiconductor performance. ${ }^{18-21}$

Considering potential future device fabrication, it was observed that the solubility profile of compound $\mathbf{3 c}$ was appropriate for production of good quality films on UV-ozone-cleaned glass by spin coating, particularly from chloroform or 1,2-dichloroethane solutions (see Supplementary Material).

Thermal Gravimetric Analysis (TGA) of compounds $3 \mathbf{b}$ and 3c suggested thermal stability to above $200{ }^{\circ} \mathrm{C}$ (see Supplementary Material, also for Differential Scanning Calorimetry (DSC) curves).

The electron-deficient nature of the 1,7-dicyano-2,8-bis(dialkylamino)-3,9-diazaperylenes 3 was evidenced by the reaction of compound $3 \mathrm{c}$ with excess of 4 -chloro- $N$-methylaniline and $\mathrm{KOH}$ in $\mathrm{DMSO},{ }^{8}$ which afforded a mixture of the dark, greenish blue bis-anilino compound $\mathbf{5}$ and the purplish, navy blue mono-substituted product 6 (Scheme 2).

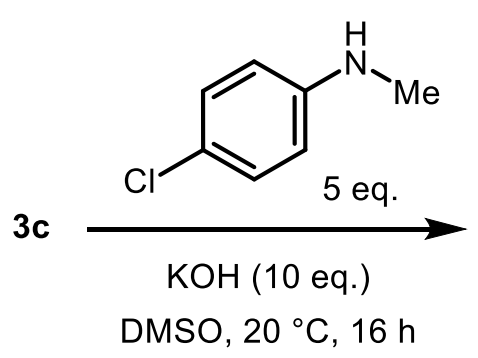<smiles></smiles><smiles>CCNc1nc2cccc3c4c(C#N)c(NCC)ccc4c4c(N(C)c5ccc(Cl)cc5)c(N(C)c5ccc(Cl)cc5)c(n1)c2c4-3</smiles>

\section{Scheme 2}

The structure of bis-adduct 5 was supported by X-ray crystallography (Figure 4), which confirmed new substitution at the $\mathrm{C} 4$ and $\mathrm{C} 10$ positions. The C4-substituted structure of mono-adduct 6 was assumed by analogy. 


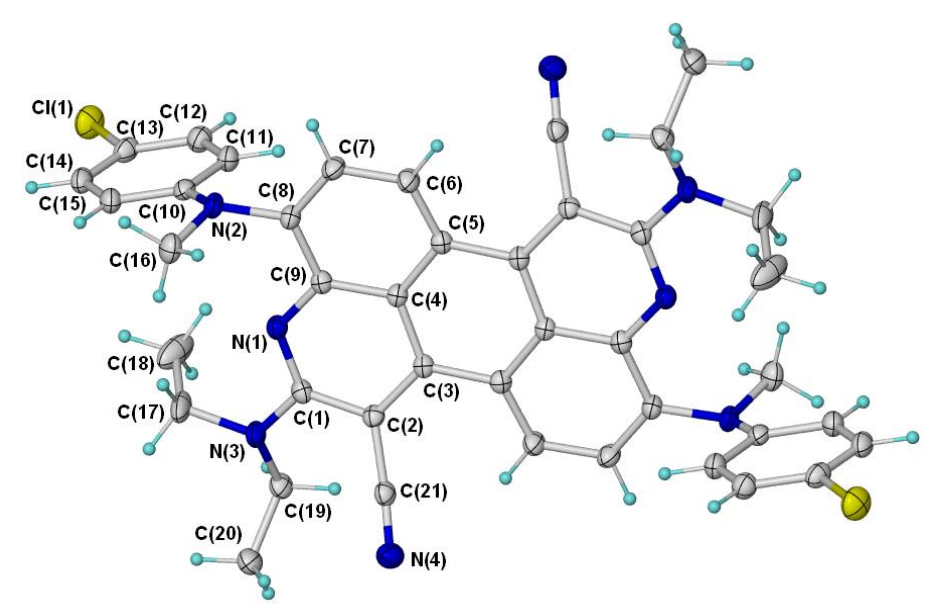

Figure 4. Crystal structure of bis-anilino adduct 5 with $50 \%$ thermal ellipsoids and hydrogen atoms as spheres of arbitrary size. The molecule lies on a crystallographic inversion center relating the two halves of the molecule. Only the unique atoms have been labelled. Solvent $\mathrm{CHCl}_{3}$ molecule is not shown.

The crystal structure of bis-anilino adduct 5 showed a different form of $\pi-\pi$ stacking, compared to that of compound 3c. In crystals of adduct 5 , the central polycyclic core is stacked between peripheral chlorophenyl rings of two adjacent molecules (see Figures 5 \& 6), rather than the pentacyclic cores of adjacent molecules, as in compound 3c (see Figure 2).

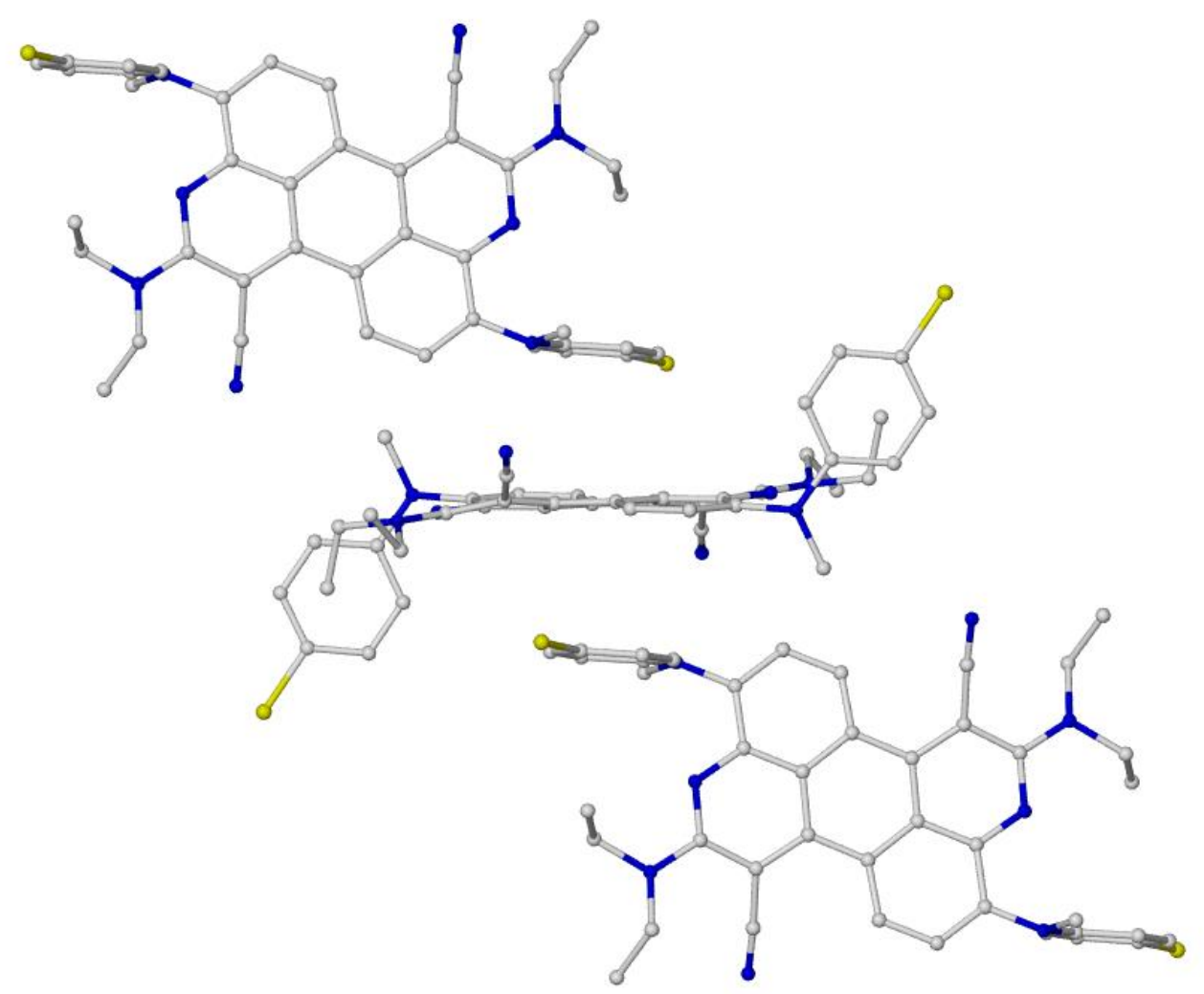

Figure 5. Ball and stick representation showing $\pi$ - $\pi$-stacking of the central polycyclic core of compound $\mathbf{5}$ between two $\mathrm{Cl}-\mathrm{Ph}$ rings from adjacent molecules. 


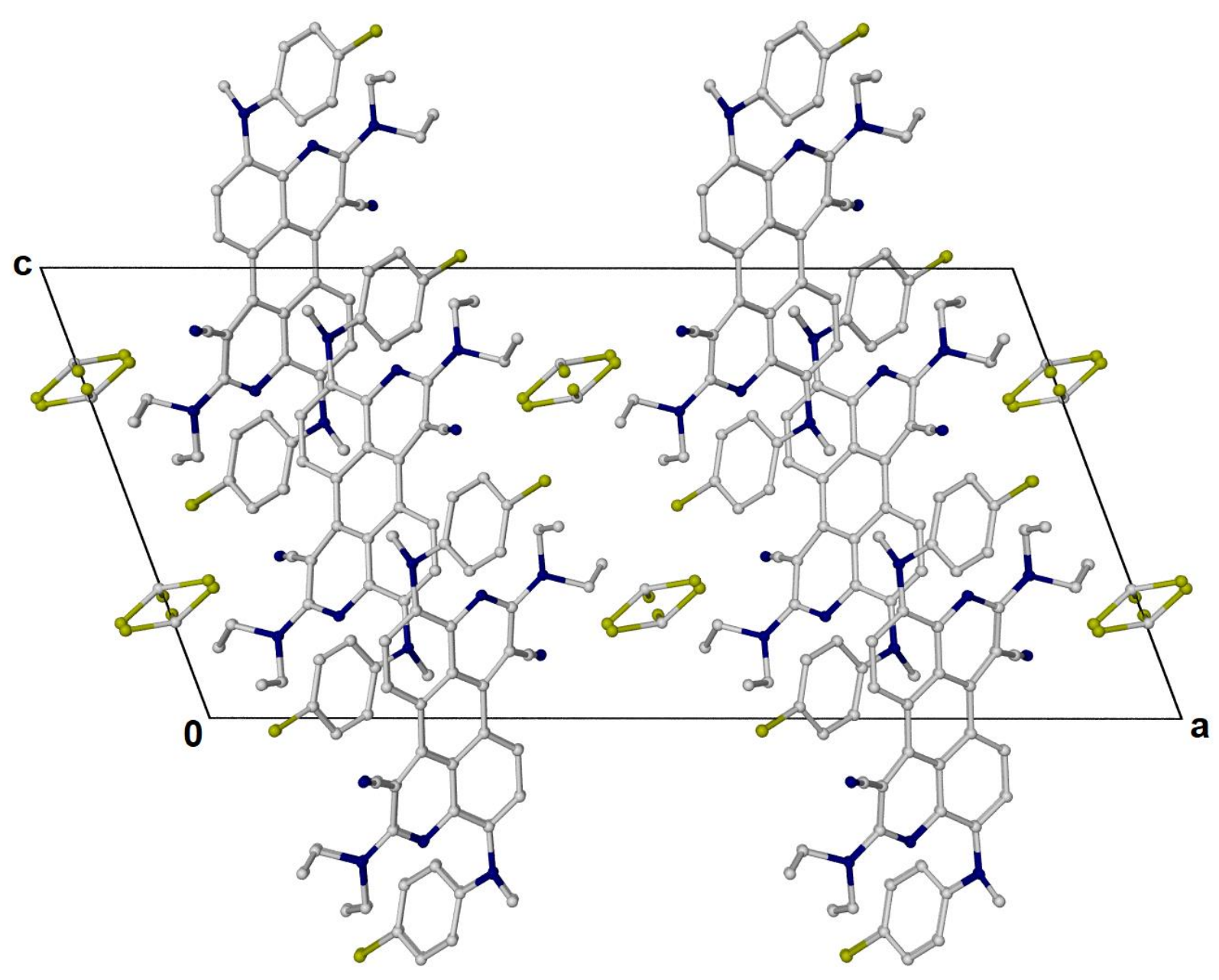

Figure 6. Cell contents of compound $\mathbf{5}$ as viewed down the $b$ axis, showing the layered, supramolecular, 2-D sheet structure. Solvent $\mathrm{CHCl}_{3}$ molecules are shown.

The plane separation between the chlorophenyl moiety and the core of an adjacent molecule is about 3.7 $\AA$; perhaps slightly long (possibly due to steric repulsion from the $\mathrm{Cl}$ ) for efficient electron transfer. The two peripheral chlorophenyl substituents on the diazaperylene core each interact with a further two core molecules forming a chain, thus giving a 2D network (Figure 6). Although there is a connection between the molecules in two dimensions, such an arrangement is not a continuous $\pi-\pi$ stack in the usual sense. The type of solid-state packing of compound 5 (Figures $5 \& 6$ ) does not augur well for likely high charge mobility in a thin film of this compound, which would be required for use as an OPV material.

The bis-dialkylamino substituents of compounds $\mathbf{3}$, as well as the anilino moieties of compounds $\mathbf{5}$ and $\mathbf{6}$, can be considered somewhat electron-donating and therefore not a desirable feature in electron-accepting (n-type) small molecules for potential organic electronics applications. The dialkylamino groups also represent a "redox liability"; cyclic voltammetry experiments showed that compounds 3c (Figure 7) and 3d (Supplementary Material) underwent two reversible reductions, but an irreversible oxidation. 


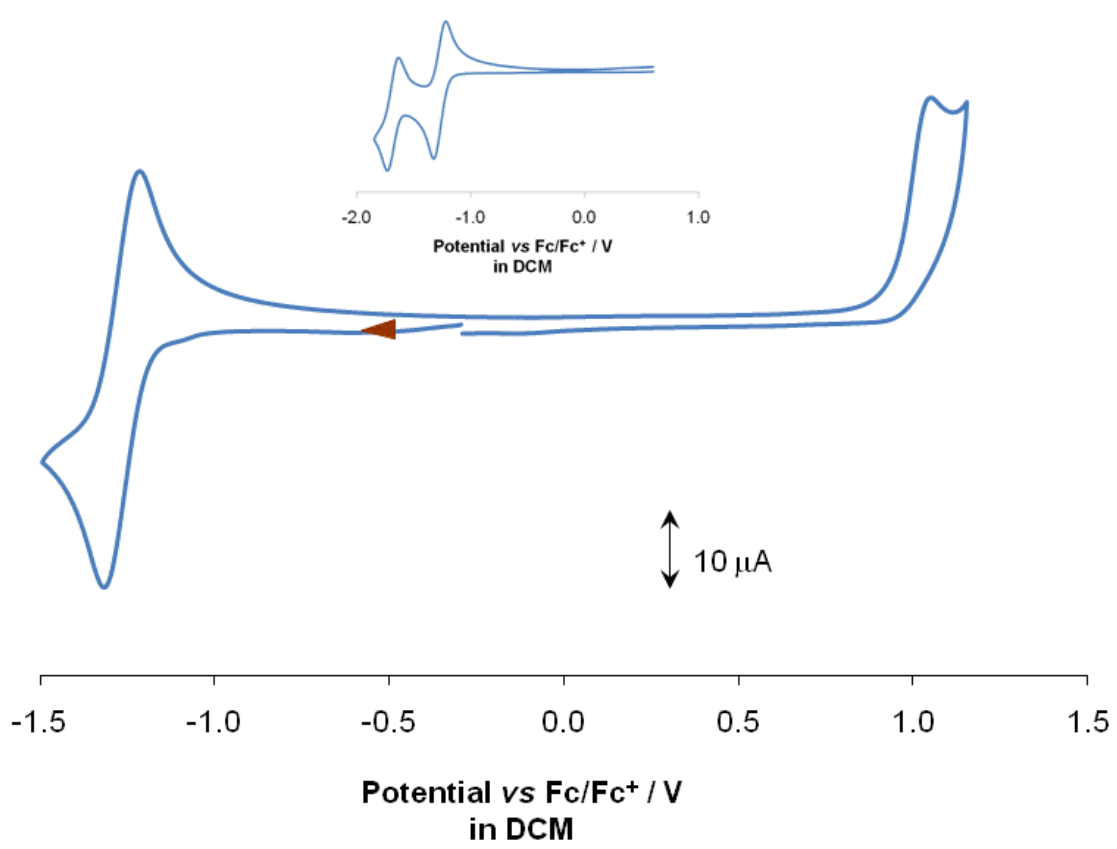

Figure 7. Cyclic voltammogram of compound 3c showing two reversible reductions and an irreversible oxidation.

Consequently, we sought to establish chemistry which would enable access to 3,9-diazaperylene compounds with a broader range of substituents at $\mathrm{C} 2$ and $\mathrm{C} 8$.

Specifically, structures in which the nitrogen-centered substituents at C2 and C8 were replaced with (conjugated) carbon-linked moieties were targeted. Initial attempts at Friedländer-style synthesis of 2,8diphenyl-1,7-dicyano-3,9-diazaperylene via reaction of 1,5-diaminoanthraquinone 1 with benzoylacetonitrile in the presence of either ceric ammonium nitrate/MeOH, ${ }^{22}$ chlorotrimethylsilane/DMF, ${ }^{23}$ or catalytic sulfuric acid/acetic acid, ${ }^{24}$ were unsuccessful.

An effective synthetic protocol was eventually established and is outlined in Scheme 3 . Reaction of 1,5-diaminoanthraquinone 1 with cyanoacetic acid in the presence of diphenyl phosphite and pyridine gave the bis-cyanoacetamide intermediate 7 which was cyclized by heating with DBU in acetonitrile to afford 1,7dicyano-3,9-diazaperylene-2,8-diol bis DBU salt 8. Treatment of the salt 8 with triflic anhydride in the presence of pyridine gave the very poorly soluble bis-triflate $\mathbf{9}$ (Scheme 3), which we envisaged could be a suitable substrate for palladium-catalyzed coupling reactions (e.g., Suzuki, Stille, and Sonogashira variants) to introduce conjugated groups at $\mathrm{C} 2$ and $\mathrm{C} 8$ of the diazaperylene core. Prior to synthesis of the bis-triflate 9, the preparation of the bis-chloro analogue was investigated. Heating the bis DBU salt 8 with either phosphoryl chloride/triethylamine hydrochloride, ${ }^{25}$ phosphoryl chloride/DMF, ${ }^{26}$ or thionyl chloride/DMF, ${ }^{27}$ afforded, after aqueous workup, extremely insoluble solids, which were exceedingly difficult to characterize.

In preparation for Sonogashira coupling reactions, ${ }^{28-30}$ where the triflate groups of compound 9 would be replaced with various conjugated alkyne moieties, a small but diverse set of alkyne building blocks 10a-d was assembled. These compounds included moieties successfully demonstrated in organic electronics applications: trialkylsilyl 1,4,5,31 $(\mathbf{1 0 a})$, alkoxyphenyl ${ }^{1-6}(\mathbf{1 0 b})$, as well as two uncommon moieties, 1-hexylpyrazol-4-yl (10c) and 1-(hexyloxy)cyclohexane (10d). Triisopropylsilylacetylene 10a is commercially available; the other compounds 10b-d were synthesized by modification of literature procedures. ${ }^{32,33}$ 
Sonogashira-coupling reactions ${ }^{28-30}$ between bis-triflate 9 and each of alkynes 10a-d, utilizing conditions involving bis(triphenylphosphine)palladium(II) dichloride, cuprous iodide and triethylamine in THF, provided the corresponding 2,8-bisalkynyl-substituted 1,7-dicyano-3,9-diazaperylenes 11a-d, respectively, in modest $40-55 \%$ yields (Scheme 3 ).<smiles>Nc1cccc2c1C(=O)c1cccc(N)c1C2=O</smiles>

1

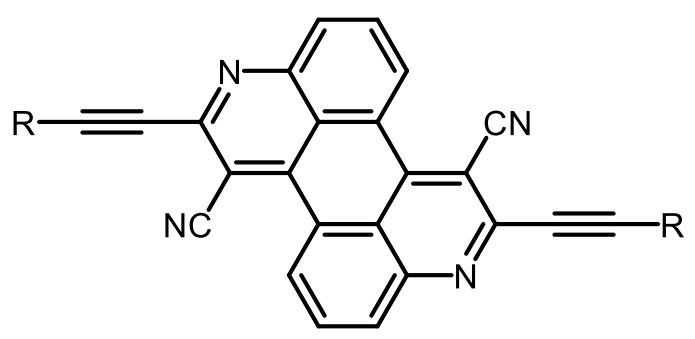

11a-d

py, DMF $120^{\circ} \mathrm{C}, 7 \mathrm{~h}$

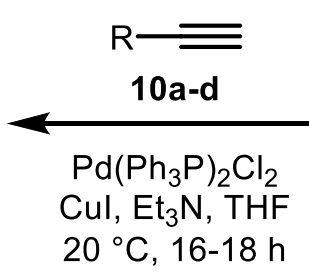

$20{ }^{\circ} \mathrm{C}, 16-18 \mathrm{~h}$<smiles>CCCC(=O)NC</smiles>
$60^{\circ} \mathrm{C}, 3 \mathrm{~h}$<smiles></smiles>

$8(72 \%)$ \begin{tabular}{c|l}
$\mathrm{Tf}_{2} \mathrm{O}$ & $\mathrm{CH}_{3} \mathrm{CN}$ \\
py & $\mathrm{CO}^{\circ} \mathrm{C}, 8 \mathrm{~h}$
\end{tabular}<smiles>N#CC1=c2c3c4c(cccc4c(C#N)c(OS(=O)(=O)C(F)(F)F)nc4cccc2c4=3)N=C1OS(=O)(=O)C(F)(F)F</smiles>

$9(88 \%)$

a $\mathrm{R}=\operatorname{TIPS}(56 \%)$<smiles>[R][Y]([H])(C)Cc1cnn(CCCCCC)c1</smiles>

b<smiles>[R][Y]([H])([H])c1cccc(OCCCCCC)c1</smiles><smiles>CCCCCCOC1(C=[R]Cl)CCCCC1</smiles>

\section{Scheme 3}

Stille coupling of bis-triflate 9 with 2-(tributylstannyl)-5-hexylthiophene 34,35 afforded the directly "corearylated" product, 2,8-bis(5-hexylthien-2-yl)-1,7-dicyano-3,9-diazaperylene (12), in 46\% yield (Scheme 4). Attempts to prepare bis-thienyl compound $\mathbf{1 2}$ via a Suzuki reaction between bis-triflate $\mathbf{9}$ and 5-hexyl-2thiopheneboronic acid pinacol ester were unsuccessful.

Bis-ethynyl compounds 11a-d were isolated as stable yellow solids, while the bis-thienyl compound $\mathbf{1 2}$ was a stable orange solid. All five compounds 11a-d are new derivatives of rare 3,9-diazaperylenes. 


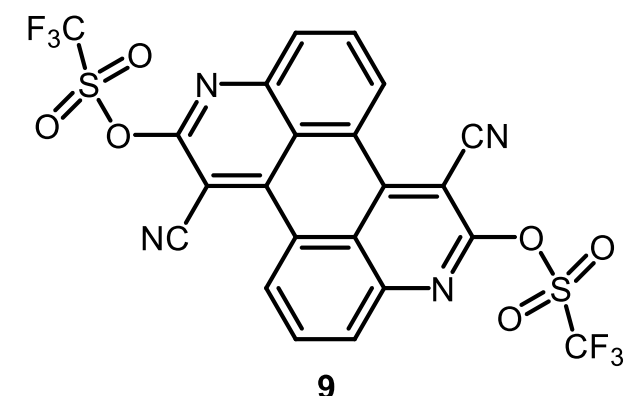

9

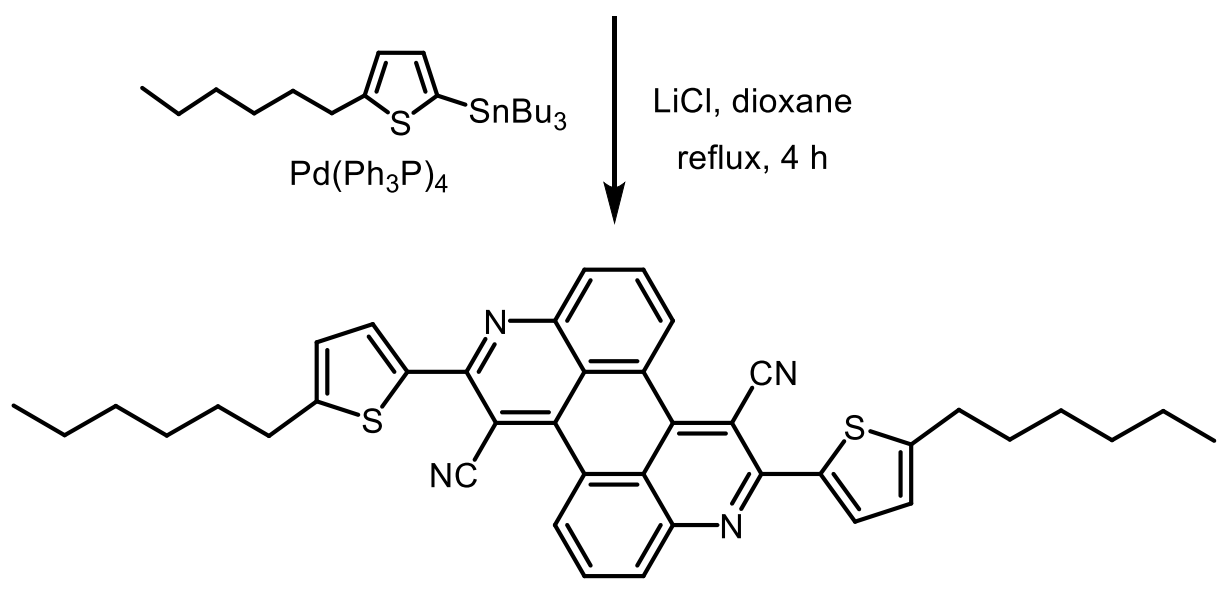

$12(46 \%)$

\section{Scheme 4}

The UV-vis spectra of compounds $\mathbf{3 b}, \mathbf{3 c}, \mathbf{3 d}, \mathbf{5}, \mathbf{6}, \mathbf{1 1} \mathbf{a}-\mathbf{d}$, and $\mathbf{1 2}$ were recorded (Figure 8).

Only the blue-colored anilino compounds 5 and 6 showed any significant absorption in the $600-700 \mathrm{~nm}$ region, an energy rich part of the visible spectrum over which the commonly studied n-type fullerene acceptors have low absorption, and a targeted region for absorption by candidate electron accepting $n$-type compounds. The red-colored compounds 3 absorbed up to wavelengths of $600 \mathrm{~nm}$, but compounds 11 and 12 (yellow to orange in color) only absorbed at lower wavelengths, typically $<500 \mathrm{~nm}$, which was indicative of an inadequate absorption profile for potential organic photovoltaic application. 

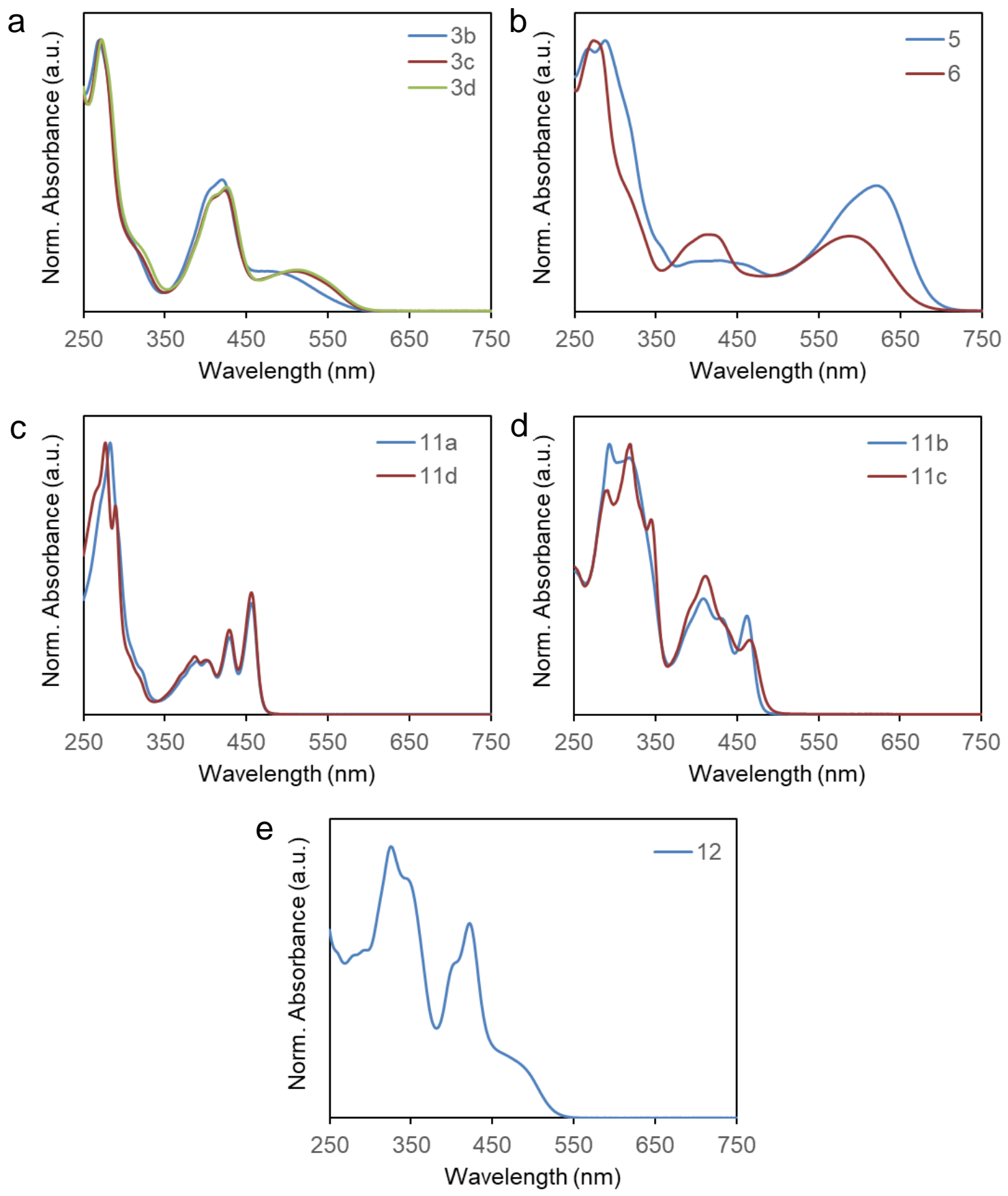

Figure 8. UV-vis spectra of compounds: (a) 3b, 3c, 3d; (b) 5, 6; (c) 11a, 11d; (d) 11b, 11c; (e) 12.

\section{Conclusions}

Concise synthetic methodology for a range of new 2,8-disubstituted-1,7-dicyano-3,9-diazaperylenes has been developed. These synthetic protocols start from the cheap, readily available 1,5-diaminoanthraquinone, and enable the introduction of various tertiary-amino, substituted-ethynyl, and aryl groups at the C2 and C8 positions, as well as incorporation of aryl-amino groups at the C4 and C10 positions, of the rare 3,9diazaperylene core structure. 
This work provides synthetic pathways to a variety of highly substituted diazaperylenes, enabling the tuning of physical and optoelectronic properties. Such methodology, perhaps in combination with the related, complementary methodology developed by Yi Liu and co-workers, ${ }^{10}$ may find use in the discovery of new materials for organic photovoltaic devices or other organic electronic applications.

\section{Experimental Section}

Methods and Materials. Melting points were determined using a Reichert hot stage microscope or a Gallenkamp MPD350.BM2.5 apparatus and are uncorrected. Analytical thin layer chromatography (TLC) was carried out on Merck Kieselgel $60 \mathrm{~F}_{254}$ silica aluminium backed sheets. Developed plates were visualized with either UV light $(254 \mathrm{~nm}$ ) or a solution of $10 \%(\mathrm{w} / \mathrm{v})$ phosphomolybdic acid in EtOH followed by heating. Radial chromatography was performed on a Harrison Research Chromatotron (Model 7924T) using 1, 2, or 4 mm thick silica plates (Merck silica gel $60 \mathrm{PF}_{254}$ containing gypsum). Light petroleum refers to a fraction boiling between 40 and $60{ }^{\circ} \mathrm{C} .{ }^{1} \mathrm{H}$ NMR spectra were recorded on a Bruker AC-200 or a Bruker Av400 spectrometer at 200 and $400 \mathrm{MHz}$, respectively. ${ }^{13} \mathrm{C}$ NMR spectra were recorded at room temperature on a Bruker AC-200 at $50 \mathrm{MHz}$, a Varian Gemini 300 at 75 MHz, a Bruker Av400 at $100.6 \mathrm{MHz}$ or a Bruker DRX500 at $125.75 \mathrm{MHz}$. Electron impact (EI) mass spectra were recorded on a ThermoQuest MAT95XL mass spectrometer using ionization energy of $70 \mathrm{eV}$. Only the major fragments are given with their relative abundances shown in parentheses. Accurate mass measurements were obtained with a resolution of 5000-10000 using perfluorokerosene as the internal reference. Electrospray ionization (ESI) mass spectrometric analyses were performed on a Thermo Scientific Q Exactive mass spectrometer fitted with a high-resolution HESI-II ion source. Positive and negative ions were recorded in an appropriate mass range at 140,000 mass resolution. The probe was used with $0.3 \mathrm{~mL} / \mathrm{min}$ flow of solvent (usually $\mathrm{MeOH}$ ), and a solution of Reserpine was also introduced into the probe during the experiments to serve as a lock mass in both positive and negative ion modes. The nitrogen nebulizing/desolvation gas used for vaporization was heated to $350{ }^{\circ} \mathrm{C}$ in these experiments. The sheath gas flow rate was set to 35 and the auxiliary gas flow rate to 25 (both arbitrary units). The spray voltage was $3.0 \mathrm{kV}$ and the capillary temperature was $300{ }^{\circ} \mathrm{C}$. Some high-resolution mass spectrometric analyses were performed on a Thermo Scientific Q Exactive mass spectrometer (Thermo Scientific, Waltham, MA, USA) fitted with an ASAP ion source (M\&M Mass Spec consulting). ${ }^{36}$ The design and method of ionization have been described previously. ${ }^{37,38}$ Samples were dissolved in acetonitrile. Positive and negative ions were recorded in an appropriate mass range at 140,000 mass resolution. The APCl probe was used without flow of solvent. The nitrogen nebulizing/desolvation gas used for vaporization was heated to 450 ${ }^{\circ} \mathrm{C}$. The sheath gas flow rate was set to 25 , the auxiliary gas flow rate to 5 and the sweep gas flow rate to 2 (all arbitrary units). The discharge current was $2 \mathrm{~mA}$ and the capillary temperature was $320{ }^{\circ} \mathrm{C}$. UV-vis spectra were recorded in chloroform solution on a Perkin Elmer Lambda 1050 UV-vis Spectrophotometer. Thermal Gravimetric Analysis (TGA) was carried out on a Mettler Toledo TGA/SDTA851 and Differential Scanning Calorimetry (DSC) was performed on a Mettler Toledo DSC821. The electrochemistry (cyclic voltammetry) measurements were carried out using a Powerlab ML160 potentiostat interfaced via a Powerlab 4/20 controller to a PC running Echem for windows Ver. 1.5.2. The measurements were run in nitrogen-purged DCM with tetrabutylammonium hexafluorophosphate $(0.2 \mathrm{M})$ as the supporting electrolyte. The voltammograms were recorded using a standard 3 electrode configuration with a glassy carbon $(2 \mathrm{~mm}$ diameter) working electrode, a platinum wire counter electrode and a silver wire pseudo reference electrode. The silver wire was cleaned in concentrated nitric acid and then in concentrated hydrochloric acid to generate the $\mathrm{Ag} / \mathrm{Ag}+$ reference. Voltammograms were recorded with a sweep rate of $50-200 \mathrm{mVs}^{-1}$. The sample 
concentration was $1 \mathrm{mM}$. All potentials were referenced to the E1/2 of the ferrocene/ferrocenium couple. Microanalyses were performed at The Campbell Microanalytical Laboratory, University of Otago, Dunedin, New Zealand.

3-Oxo-3-(piperidin-1-yl)propanenitrile (2b). Prepared by a literature method ${ }^{14-16}$ as an off-white/creamcolored solid. ${ }^{1} \mathrm{H}$ NMR $\left(\mathrm{CDCl}_{3}, 200 \mathrm{MHz}\right) \delta 3.53\left(2 \mathrm{H}, \mathrm{t}, J 5.0 \mathrm{~Hz}, \mathrm{CH}_{2} \mathrm{~N}\right), 3.43\left(2 \mathrm{H}, \mathrm{s}, \mathrm{CH}_{2} \mathrm{CN}\right), 3.36(2 \mathrm{H}, \mathrm{t}, J 5.0 \mathrm{~Hz}$, $\left.\mathrm{CH}_{2} \mathrm{~N}\right), 1.73-1.47\left(6 \mathrm{H}, \mathrm{m}, \mathrm{CH}_{2} \mathrm{CH}_{2} \mathrm{CH}_{2}\right) .{ }^{13} \mathrm{C} \mathrm{NMR}\left(\mathrm{CDCl}_{3}, 50 \mathrm{MHz}\right) \delta 159.81,114.25,47.50,43.54,26.04,25.20$, 24.95, 24.05.

2-Cyano- $\mathbf{N}, \mathbf{N}$-diethylacetamide (2c). Prepared by adapting the procedure of Cossey et al. ${ }^{14}$ Thus, a mixture of ethyl cyanoacetate $(8.65 \mathrm{~mL}, 9.17 \mathrm{~g}, 80 \mathrm{mmol})$ and diethylamine $(11.35 \mathrm{~mL}, 7.98 \mathrm{~g}, 110 \mathrm{mmol})$ was placed in a $20 \mathrm{~mL}$ microwave reactor vial. Five such mixtures were prepared. Each vial was sealed and heated at $180^{\circ} \mathrm{C}$ for 30 mins in a Biotage Initiator 60 microwave reactor. The cooled reaction mixtures were combined and the whole was vacuum distilled to afford the title compound $2 \mathrm{c}(43.90 \mathrm{~g}, 78 \%)$ as a colorless oil, bp 99-100 ${ }^{\circ} \mathrm{C} / 0.1 \mathrm{mmHg} .{ }^{1} \mathrm{H}$ NMR $\left(\mathrm{CDCl}_{3}, 400 \mathrm{MHz}\right) \delta 3.50\left(2 \mathrm{H}, \mathrm{s}, \mathrm{CH}_{2} \mathrm{CN}\right), 3.38\left(2 \mathrm{H}, \mathrm{q}, J 7.2 \mathrm{~Hz}, \mathrm{CH}_{2} \mathrm{~N}\right), 3.29(2 \mathrm{H}, \mathrm{q}$, J $\left.7.2 \mathrm{~Hz}, \mathrm{CH}_{2} \mathrm{~N}\right), 1.22\left(3 \mathrm{H}, \mathrm{t}, J 7.2 \mathrm{~Hz}, \mathrm{CH}_{3}\right), 1.13\left(3 \mathrm{H}, \mathrm{t}, J 7.2 \mathrm{~Hz}, \mathrm{CH}_{3}\right) .{ }^{13} \mathrm{C} \mathrm{NMR}\left(\mathrm{CDCl}_{3}, 125 \mathrm{MHz}\right) \delta 160.90$, $114.56,42.63,40.77,24.89,13.89,12.59$.

2-Cyano- $\mathbf{N}, \mathbf{N}$-dipropylacetamide (2d). Dipropylamine was employed in the above procedure to prepare the title compound $2 \mathrm{~d}(62 \%)$ as a colorless oil, bp $115-117^{\circ} \mathrm{C} / 0.1 \mathrm{mmHg} .{ }^{1} \mathrm{H} \mathrm{NMR}\left(\mathrm{CDCl}_{3}, 400 \mathrm{MHz}\right) \delta 3.46(2 \mathrm{H}, \mathrm{s}$, $\left.\mathrm{CH}_{2} \mathrm{CN}\right), 3.21-3.13\left(2 \mathrm{H}, \mathrm{m}, \mathrm{CH}_{2} \mathrm{~N}\right), 3.11-3.03\left(2 \mathrm{H}, \mathrm{m}, \mathrm{CH}_{2} \mathrm{~N}\right), 1.57-1.37\left(4 \mathrm{H}, \mathrm{m}, \mathrm{CH}_{2}\right), 0.87-0.73\left(6 \mathrm{H}, \mathrm{m}, \mathrm{CH}_{3}\right) .{ }^{13} \mathrm{C}$ $\operatorname{NMR}\left(\mathrm{CDCl}_{3}, 100 \mathrm{MHz}\right) \delta 161.47,114.61,50.08,48.02,24.99,21.86,20.52,11.14,10.97$.

2,8-Di(piperidin-1-yl)benzo[1,2,3-de:4,5,6-d'e']diquinoline-1,7-dicarbonitrile (3b). Prepared by adapting the procedure of Tatke and Seshadri. ${ }^{7}$ Thus, a solution of the cyanoacetamide $\mathbf{2 b}(1.22 \mathrm{~g}, 8 \mathrm{mmol})$ in 1,4 -dioxane $(5 \mathrm{~mL})$ was added slowly with stirring to phosphorus oxychloride $(0.73 \mathrm{~mL}, 1.23 \mathrm{~g}, 8 \mathrm{mmol})$ under $\mathrm{N}_{2}$ and the mixture was stirred at $70^{\circ} \mathrm{C}$ for 90 mins. With a slight positive pressure of nitrogen applied, the reaction vessel was briefly opened and 1,5-diaminoanthraquinone $(0.48 \mathrm{~g}, 2 \mathrm{mmol})$ was added. The vessel was closed and the resulting mixture was heated at $80^{\circ} \mathrm{C}$ with stirring under $\mathrm{N}_{2}$ for $5.5 \mathrm{~h}$. The reaction mixture was cooled and then added portionwise with vigorous stirring to a mixture of saturated, aqueous sodium hydrogen carbonate solution $\left(50 \mathrm{~mL}\right.$ ) in a beaker ( $250 \mathrm{~mL}$ size or larger) (CAUTION - frothing and liberation of $\mathrm{CO}_{2}$ gas!). During this process some chloroform $(\sim 10 \mathrm{~mL})$ was added to enable continued stirring. The resulting two-phase mixture was filtered to remove brown-black, chloroform-insoluble, unidentified by-product(s). The aqueous phase of the filtrate was extracted with chloroform $(2 \times 40 \mathrm{~mL})$. The combined organic phase was washed with water $(70 \mathrm{~mL})$, brine $(30 \mathrm{~mL})$, then dried $\left(\mathrm{MgSO}_{4}\right)$ and evaporated under reduced pressure. The residual dark red-brown waxy solid (1.36 g) was purified by chromatography over silica gel. The crude mixture was preabsorbed (using chloroform) onto silica gel ( $4 \mathrm{~g})$. Elution with $50 \% \mathrm{DCM}$ in light petroleum (bp $40-60{ }^{\circ} \mathrm{C}$ ) afforded the side product 6-chloro-2,4-di(piperidin-1-yl)nicotinonitrile (4b) ${ }^{14}(422 \mathrm{mg}, 35 \%)$ as a pale honeycolored oil (the color of which darkened on standing). (Found: $\mathrm{M}^{+\bullet}$ 304.1454. $\mathrm{C}_{16} \mathrm{H}_{21}{ }^{35} \mathrm{CIN}_{4}$ requires: $\mathrm{M}^{+\bullet}$ 304.1449). ${ }^{1} \mathrm{H}$ NMR $\left(\mathrm{CDCl}_{3}, 400 \mathrm{MHz}\right) \delta 6.13(1 \mathrm{H}, \mathrm{s}, \mathrm{ArH}), 3.63-3.57\left(4 \mathrm{H}, \mathrm{m}, 2 \times \mathrm{CH}_{2} \mathrm{~N}\right), 3.42-3.36(4 \mathrm{H}, \mathrm{m}$, $\left.2 \times \mathrm{CH}_{2} \mathrm{~N}\right), 1.76-1.62\left(12 \mathrm{H}, \mathrm{m}, 2 \times \mathrm{CH}_{2} \mathrm{CH}_{2} \mathrm{CH}_{2}\right)$. MS $\mathrm{m} / \mathrm{z}(\mathrm{EI}) 304 / 306\left(100 / 33 \%, \mathrm{M}^{+\bullet}\right)$. Further elution with the same solvent and then DCM afforded the title compound $\mathbf{3 b}(341 \mathrm{mg}, 36 \%)$ as a tomato red colored powder. Further purification was achieved by recrystallization from $\mathrm{DCM} /$ light petroleum (bp $40-60{ }^{\circ} \mathrm{C}$ ), which gave intense orange colored crystals, $\mathrm{mp} 282-283^{\circ} \mathrm{C}$. (Found: $\mathrm{C} 76.81 \%, \mathrm{H} 5.59 \%, \mathrm{~N} 17.74 \% . \mathrm{C}_{30} \mathrm{H}_{26} \mathrm{~N}_{6}$ requires: $\mathrm{C}$ 76.57\%, $\mathrm{H}$ 5.57\%, N 17.86\%. Found: $\mathrm{M}^{+\bullet}$ 469.2138. $\mathrm{C}_{30} \mathrm{H}_{25} \mathrm{~N}_{6}$ requires: $\mathrm{M}^{+\bullet}$ 469.2135). ${ }^{1} \mathrm{H} \mathrm{NMR}\left(\mathrm{CDCl}_{3}, 400\right.$ $\mathrm{MHz}) \delta 9.25(2 \mathrm{H}, \mathrm{dd}, J 7.7,1.0 \mathrm{~Hz}, \mathrm{ArH}), 7.95(2 \mathrm{H}, \mathrm{dd}, J 8.4,1.0 \mathrm{~Hz}, \mathrm{ArH}), 7.85(2 \mathrm{H}, \mathrm{dd}, J 8.4,7.7 \mathrm{~Hz}, \mathrm{ArH})$, $3.67\left(8 \mathrm{H}, \mathrm{t}, J 5.3 \mathrm{~Hz}, 4 \times \mathrm{CH}_{2} \mathrm{~N}\right), 1.92-1.84\left(8 \mathrm{H}, \mathrm{m}, 2 \times \mathrm{CH}_{2} \mathrm{CH}_{2}\right), 1.80-1.72\left(4 \mathrm{H}, \mathrm{m}, 2 \times \mathrm{CH}_{2}\right) .{ }^{13} \mathrm{C} \mathrm{NMR}\left(\mathrm{CDCl}_{3}, 50 \mathrm{MHz}\right)$ 
$\delta 162.48,148.71,144.54,132.06,131.81,126.85,125.42,119.87,119.48,93.91,51.51,25.81,24.54 . \mathrm{MS}$ $\mathrm{m} / \mathrm{z}$ (El) $469\left(100 \%, \mathrm{M}^{+\bullet}\right)$. UV-vis [ $\mathrm{CHCl}_{3}, \lambda_{\max }, \mathrm{nm}$ (rel. int.)]: 270 (1.00), 423 (0.48), 485 (0.15).

2,8-Bis(diethylamino)benzo[1,2,3-de:4,5,6-d'e']diquinoline-1,7-dicarbonitrile (3c). A solution of the cyanoacetamide $2 \mathrm{c}(3.36 \mathrm{~g}, 24 \mathrm{mmol})$ in 1,4-dioxane $(10 \mathrm{~mL})$ was added slowly with stirring to phosphorus oxychloride $\left(2.2 \mathrm{~mL}, 3.68 \mathrm{~g}, 24 \mathrm{mmol}\right.$ ) under $\mathrm{N}_{2}$ (bubbler) and the mixture was stirred for approx. $30 \mathrm{mins}$ at room temperature. With a slight positive pressure of nitrogen applied, the reaction vessel was briefly opened and 1,5-diaminoanthraquinone $(1.43 \mathrm{~g}, 6 \mathrm{mmol})$ was added. The vessel was closed, and the resulting mixture was heated at $80^{\circ} \mathrm{C}$ with stirring under $\mathrm{N}_{2}$ for $4 \mathrm{~h}$. The reaction mixture was cooled and then added portionwise with vigorous stirring to a mixture of saturated, aqueous sodium hydrogen carbonate solution $(100 \mathrm{~mL})$ in a beaker $\left(250 \mathrm{~mL}\right.$ size or larger) (CAUTION - frothing and liberation of $\mathrm{CO}_{2}$ gas!). During this process some chloroform ( $30-40 \mathrm{~mL}$ ) was added to enable continued stirring. The resulting two-phase mixture was filtered to remove brown-black, chloroform-insoluble, unidentified by-product(s). The aqueous phase of the filtrate was extracted with chloroform $(2 \times 50 \mathrm{~mL})$. The combined organic phase was washed with water $(70 \mathrm{~mL})$, then dried $\left(\mathrm{MgSO}_{4}\right)$ and evaporated under reduced pressure. The residual red-brown waxy gum $(4.32 \mathrm{~g})$ was purified by chromatography over silica gel. The crude mixture was pre-absorbed onto silica gel ( 5:3 wt : wt silica gel : sample). Elution with 50\% DCM in light petroleum afforded the side product 6chloro-2,4-bis(diethylamino)nicotinonitrile $(\mathbf{4 c})^{14}(850 \mathrm{mg}, 25 \%)$ as a pale honey-colored oil (the color of which darkened on standing). ${ }^{1} \mathrm{H}$ NMR $\left(\mathrm{CDCl}_{3}, 400 \mathrm{MHz}\right) \delta 6.07(1 \mathrm{H}, \mathrm{s}, \mathrm{ArH}), 3.61\left(4 \mathrm{H}, \mathrm{q}, J 7.0,2 \times \mathrm{CH}_{2} \mathrm{~N}\right), 3.50(4 \mathrm{H}, \mathrm{q}$, J 7.0, $\left.2 \times \mathrm{CH}_{2} \mathrm{~N}\right), 1.27\left(6 \mathrm{H}, \mathrm{t}, J 7.0,2 \times \mathrm{CH}_{3}\right), 1.26\left(6 \mathrm{H}, \mathrm{t}, J 7.0,2 \times \mathrm{CH}_{3}\right)$. Further elution with the same solvent and then DCM afforded the title compound $3 \mathrm{c}(600 \mathrm{mg}, 22 \%)$ as a deep tomato red powder. Recrystallization from DCM/light petroleum gave clusters of very deep red prisms of suitable quality for X-ray crystallography, mp 188-189 ${ }^{\circ} \mathrm{C}$. (Found: $\mathrm{C} 75.16 \%, \mathrm{H} 5.79 \%, \mathrm{~N} 18.77 \% . \mathrm{C}_{28} \mathrm{H}_{26} \mathrm{~N}_{6}$ requires: $\left.\mathrm{C} 75.31 \%, \mathrm{H} 5.87 \%, \mathrm{~N} 18.82 \%\right) .{ }^{1} \mathrm{H}$ NMR $\left(\mathrm{CDCl}_{3}, 400 \mathrm{MHz}\right) \delta 9.14(2 \mathrm{H}, \mathrm{dd}, J 7.6,1.1 \mathrm{~Hz}, \mathrm{ArH}), 7.86(2 \mathrm{H}, \mathrm{dd}, J 8.4,1.1 \mathrm{~Hz}, \mathrm{ArH}), 7.78(2 \mathrm{H}, \mathrm{dd}, J 8.3$, $7.7 \mathrm{~Hz}, \mathrm{ArH}), 3.74\left(8 \mathrm{H}, \mathrm{t}, J 7.0 \mathrm{~Hz}, 4 \times \mathrm{CH}_{2} \mathrm{~N}\right), 1.36\left(12 \mathrm{H}, \mathrm{t}, J 7.0 \mathrm{~Hz}, 4 \times \mathrm{CH}_{3}\right) .{ }^{13} \mathrm{C} \mathrm{NMR}\left(\mathrm{CDCl}_{3}, 100 \mathrm{MHz}\right) \delta 160.41$, 148.62, 144.86, 131.87, 131.44, 126.77, 124.96, 120.17, 118.92, 91.73, 45.26, 13.08. MS m/z (EI) 445 (100\%, $\mathrm{M}^{+\bullet}$ ). UV-vis $\left[\mathrm{CHCl}_{3}, \lambda_{\max }, \mathrm{nm}\right.$ (rel. int.)]: 273 (1.00), 425 (0.44), 517 (0.14).

2,8-Bis(dipropylamino)benzo[1,2,3-de:4,5,6-d'e']diquinoline-1,7-dicarbonitrile (3d). The cyanoacetamide $2 \mathrm{~d}$ was employed in the above procedure (on $2 \mathrm{mmol}$ scale) to prepare the title compound $\mathbf{3 d}(62 \mathrm{mg}, 12 \%)$ as a deep claret colored powder, mp $160-162{ }^{\circ} \mathrm{C}$. (Found: $\mathrm{C} 76.26 \%, \mathrm{H} 6.71 \%, \mathrm{~N} 16.74 \% . \mathrm{C}_{32} \mathrm{H}_{34} \mathrm{~N}_{6}$ requires: $\mathrm{C}$

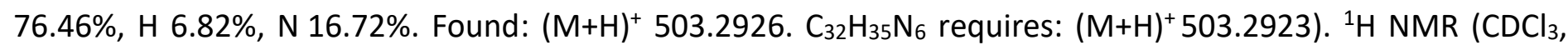
$400 \mathrm{MHz}) \delta 9.18(2 \mathrm{H}, \mathrm{dd}, J$ 7.5, $1.1 \mathrm{~Hz}, \mathrm{ArH}), 7.88(2 \mathrm{H}, \mathrm{dd}, J 8.4,1.1 \mathrm{~Hz}, \mathrm{ArH}), 7.82(2 \mathrm{H}, \mathrm{dd}, J 8.4,7.5 \mathrm{~Hz}, \mathrm{ArH})$, 3.70-3.65 $\left(8 \mathrm{H}, \mathrm{m}, 4 \times \mathrm{CH}_{2} \mathrm{~N}\right), 1.86-1.76\left(8 \mathrm{H}, \mathrm{m}, 4 \times \mathrm{CH}_{2} \mathrm{~N}\right), 1.36\left(12 \mathrm{H}, \mathrm{t}, J 7.0 \mathrm{~Hz}, 4 \times \mathrm{CH}_{3}\right) .{ }^{13} \mathrm{C} \mathrm{NMR}\left(\mathrm{CDCl}_{3}, 100\right.$ $\mathrm{MHz}) \delta 160.59,148.67,144.93,131.88,131.42,126.84,124.95,120.00,118.96,91.86,53.11,21.06,11.50 . \mathrm{MS}$ $\mathrm{m} / z(\mathrm{ES}+) 503$ [100\%, (M+H) ${ }^{+}$]. UV-vis [ $\mathrm{CHCl}_{3}, \lambda_{\max }, \mathrm{nm}$ (rel. int.)]: 273 (1.00), 429 (0.45), 520 (0.15).

The side product 6-chloro-2,4-bis(dipropylamino)nicotinonitrile (4d) was also isolated in $41 \%$ yield. ${ }^{1} \mathrm{H} \mathrm{NMR}$ $\left(\mathrm{CDCl}_{3}, 400 \mathrm{MHz}\right) \delta 6.04(1 \mathrm{H}, \mathrm{s}, \mathrm{ArH}), 3.54-3.49\left(4 \mathrm{H}, \mathrm{m}, 2 \times \mathrm{CH}_{2} \mathrm{~N}\right), 3.41-3.36\left(4 \mathrm{H}, \mathrm{m}, 2 \times \mathrm{CH}_{2} \mathrm{~N}\right), 1.68(8 \mathrm{H}$, sextet, J 7.5, $\left.4 \times \mathrm{xH}_{2}\right), 0.95\left(6 \mathrm{H}, \mathrm{t}, J 7.4,2 \times \mathrm{CH}_{3}\right), 0.93\left(6 \mathrm{H}, \mathrm{t}, J\right.$, 7.3, $\left.2 \mathrm{xCH}_{3}\right)$.

\section{4,10-Bis[(4-chlorophenyl)(methyl)amino]-2,8-bis(diethylamino)benzo[1,2,3-de:4,5,6-d'e']diquinoline-1,7-}

dicarbonitrile (5) and 4-[(4-chlorophenyl)(methyl)amino]-2,8-bis(diethylamino)benzo[1,2,3-de:4,5,6$d^{\prime} e^{\prime}$ ]diquinoline-1,7-dicarbonitrile (6). Prepared by adapting the procedure of Tatke and Seshadri. ${ }^{8}$ Thus, a mixture of freshly pulverized potassium hydroxide $(3.0 \mathrm{~g}, 53 \mathrm{mmol})$, 4-chloro- $N$-methylaniline $(3.2 \mathrm{~g}, 23 \mathrm{mmol})$ and DMSO $(25 \mathrm{~mL})$ was stirred for 10 minutes. Compound $3 \mathrm{c}(2.0 \mathrm{~g}, 4.5 \mathrm{mmol})$ was added and the resulting mixture was stirred overnight $(16 \mathrm{~h})$ at room temperature in a loosely stoppered flask. The dark blue reaction mixture was poured into ice/water $(250 \mathrm{~mL})$ with vigorous stirring and acidified by slow addition of conc. $\mathrm{HCl}$ 
( 10 $\mathrm{mL})$. The dark greenish blue precipitate was collected by filtration and washed with water, then saturated, aqueous sodium carbonate solution and again with water. The residual dark blue solid ( $2.5 \mathrm{~g})$ was dissolved in chloroform ( $20 \mathrm{~mL}$ ) and adsorbed onto Celite ( $8 \mathrm{~g})$. The dry sample/Celite powder was loaded onto a $45 \mathrm{~mm}$ diameter $\times 5.5 \mathrm{~cm}$ high silica gel column. Elution with $50 \% \mathrm{DCM}$ in light petroleum (bp $40-60^{\circ} \mathrm{C}$ ) afforded the bis-anilino product $5(521 \mathrm{mg}, 16 \%)$ as a dark, greenish blue powder, followed by the monoanilino product 6 (563 $\mathrm{mg}, 21 \%$ ) as a purplish, navy blue powder.

5: Recrystallized from chloroform, which gave large navy-blue blocks of suitable quality for $\mathrm{X}$-ray crystallography, $\mathrm{mp} 186-187^{\circ} \mathrm{C}$. (Found: C 69.25\%, H 5.32\%, N 15.25\%; $\mathrm{M}^{+\bullet} 724.2572 . \mathrm{C}_{42} \mathrm{H}_{38}{ }^{35} \mathrm{Cl}_{2} \mathrm{~N}_{8}$ requires: C 69.51\%, H 5.28\%, N 15.44\%; $\left.\mathrm{M}^{+\bullet} 724.2591\right) .{ }^{1} \mathrm{H} N M R\left(\mathrm{CDCl}_{3}, 400 \mathrm{MHz}\right) \delta 9.08(2 \mathrm{H}, \mathrm{d}, J 8.5 \mathrm{~Hz}, \mathrm{ArH}), 7.59(2 \mathrm{H}, \mathrm{d}$, J $8.5 \mathrm{~Hz}, \mathrm{ArH}), 7.20-7.16(4 \mathrm{H}, \mathrm{m}, \mathrm{ArH}), 6.82-6.78(4 \mathrm{H}, \mathrm{m}, \mathrm{ArH}), 3.55(6 \mathrm{H}, \mathrm{s}, 2 \times N M e), 3.40(8 \mathrm{H}, \mathrm{q}, J 7.0 \mathrm{~Hz}$, $\left.4 \times \mathrm{CH}_{2} \mathrm{~N}\right), 1.14\left(12 \mathrm{H}, \mathrm{t}, J 7.0 \mathrm{~Hz}, 4 \times \mathrm{CH}_{3}\right) .{ }^{13} \mathrm{C} \mathrm{NMR}\left(\mathrm{CDCl}_{3}, 100 \mathrm{MHz}\right) \delta 158.70,148.98,146.69,145.67,142.97$, $128.72,125.43,125.22,122.20,120.57,120.28,119.59,89.39,44.62,41.90,12.84$. MS m/z (EI) 724/726/728 $\left(100 / 72 / 13 \%, \mathrm{M}^{+\bullet}\right)$. UV-vis $\left[\mathrm{CHCl}_{3}, \lambda_{\max }, \mathrm{nm}\right.$ (rel. int.)]: 270 (0.96), 290 (1.00), 627 (0.46).

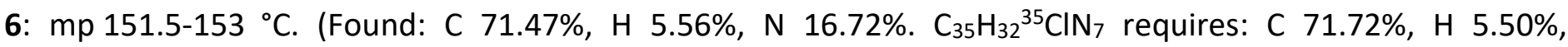
$\mathrm{N}$ 16.73\%. Found: $\mathrm{M}^{+\bullet}$ 584.2303. $\mathrm{C}_{35} \mathrm{H}_{31}{ }^{35} \mathrm{CIN}_{7}$ requires: $\left.\mathrm{M}^{+\bullet} 584.2324\right)$.

${ }^{1} \mathrm{H}$ NMR $\left(\mathrm{CDCl}_{3}, 400 \mathrm{MHz}\right) \delta 9.14(1 \mathrm{H}, \mathrm{d}, J 8.5 \mathrm{~Hz}, \mathrm{ArH}), 9.11(1 \mathrm{H}, \mathrm{dd}, J 7.6,1.0 \mathrm{~Hz}, \mathrm{ArH}), 7.87(1 \mathrm{H}, \mathrm{dd}, J 8.4$, $1.0 \mathrm{~Hz}, \mathrm{ArH}), 7.79(1 \mathrm{H}, \mathrm{dd}, J$ 8.4, 7.6 Hz, ArH), $7.61(1 \mathrm{H}, \mathrm{d}, J 8.5 \mathrm{~Hz}, \mathrm{ArH}), 7.20-7.16(2 \mathrm{H}, \mathrm{m}, \operatorname{ArH}), 6.83-6.78(2 \mathrm{H}$, $\mathrm{m}, \mathrm{ArH}), 3.77\left(4 \mathrm{H}, \mathrm{q}, J 7.0 \mathrm{~Hz}, 2 \times \mathrm{CH}_{2} \mathrm{~N}\right), 3.52(3 \mathrm{H}, \mathrm{s}, \mathrm{NMe}), 3.39\left(4 \mathrm{H}, \mathrm{q}, J 7.0 \mathrm{~Hz}, 2 \times \mathrm{CH}_{2} \mathrm{~N}\right), 1.38(6 \mathrm{H}, \mathrm{t}, J 7.0 \mathrm{~Hz}$, $\left.2 \times \mathrm{CH}_{3}\right), 1.14\left(6 \mathrm{H}, \mathrm{t}, J 7.0 \mathrm{~Hz}, 2 \times \mathrm{CH}_{3}\right) .{ }^{13} \mathrm{C} \mathrm{NMR}\left(\mathrm{CDCl}_{3}, 100 \mathrm{MHz}\right) \delta 160.61,158.58,148.97,148.60,146.82$, $145.65,145.00,143.07,131.75,131.33,128.74,127.01,125.74,125.48,125.33,124.74,121.99,120.64$, 120.36, 120.13, 119.69, 118.96, 90.79, 90.45, 45.27, 44.66, 41.96, 13.14, $12.79 . \quad M S$ $\mathrm{m} / \mathrm{z}$ (EI) 584/585/586/587/588 (90/100/64/41/13\%, $\mathrm{M}^{+\bullet}$ ). UV-vis [ $\mathrm{CHCl}_{3}, \lambda_{\max }, \mathrm{nm}$ (rel. int.)]: 277 (1.00), 428 (0.27), $590(0.28)$.

\section{3,4,5,6,7,8,9,10-Octahydro-2H-pyrimido[1,2-a]azepin-5-ium} d'e']diquinoline-2,8-bis(olate) (8).

1,7-dicyanobenzo[1,2,3-de:4,5,6-

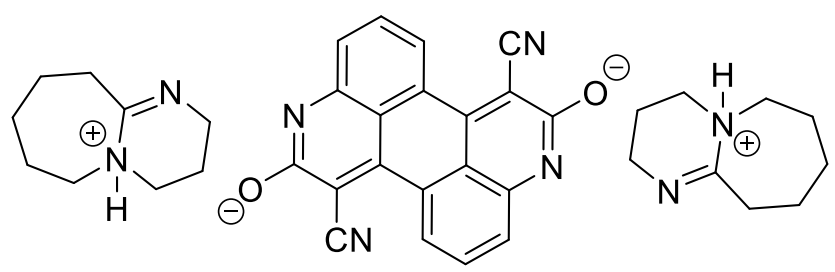

A stirred mixture of 1,5-diaminoanthraquinone (1) (15.0 g, $0.04 \mathrm{~mol})$, diphenyl phosphite (184 mL, $0.96 \mathrm{~mol})$, cyanoacetic acid $(25.0 \mathrm{~g}, 0.29 \mathrm{~mol})$, pyridine $(26 \mathrm{~mL}, 0.32 \mathrm{~mol})$, and DMF $(160 \mathrm{~mL})$ was heated at $120{ }^{\circ} \mathrm{C}$ under a nitrogen atmosphere for $7 \mathrm{~h}$ during which a yellow-brown precipitate was formed. The reaction mixture was cooled, diluted with $\mathrm{MeOH}(150 \mathrm{~mL})$ and stirred for $2 \mathrm{~h}$. The precipitate was collected, washed with $\mathrm{MeOH}$, and dried under vacuum to give the bis-cyanoacetamide intermediate $7(\sim 18 \mathrm{~g})$ as a pale orange solid. A mixture of this crude intermediate, dry acetonitrile $(540 \mathrm{~mL})$ and DBU $(28 \mathrm{~mL}, 0.18 \mathrm{~mol})$ was heated at $60^{\circ} \mathrm{C}$ for $3 \mathrm{~h}$. The red product 2 started to precipitate within moments after addition of DBU. The mixture was cooled, filtered and the collected solid was washed with acetonitrile affording the title compound 8 (29.2 g, $72 \%)$ as glistening brick-red stout needles, mp 240-241 ${ }^{\circ} \mathrm{C}$. (Found: $[\mathrm{M}-\mathrm{H}]^{-}$335.0514. $\mathrm{C}_{20} \mathrm{H}_{7} \mathrm{~N}_{4} \mathrm{O}_{2}$ requires: [M-H] $\left.{ }^{-} 335.0569\right) .{ }^{1} \mathrm{H}$ NMR (DMSO- $\left.d_{6}, 400 \mathrm{MHz}\right) \delta 8.60(2 \mathrm{H}, \mathrm{dd}, J 7.6,0.7 \mathrm{~Hz}) ; 7.52(2 \mathrm{H}, \mathrm{t}, J 8 \mathrm{~Hz}) ; 7.28(2 \mathrm{H}, \mathrm{dd}, J$ 8.3, $0.7 \mathrm{~Hz}) ; 3.46-3.41(4 \mathrm{H}, \mathrm{m}) ; 3.37(4 \mathrm{H}, \mathrm{t}, J 6.0 \mathrm{~Hz}) ; 3.21(4 \mathrm{H}, \mathrm{t}, J 6.0 \mathrm{~Hz}) ; 2.60-2.56(4 \mathrm{H}, \mathrm{m}) ; 1.83(4 \mathrm{H}$, quintet, J $6.0 \mathrm{~Hz}) ; 1.65-1.50(12 \mathrm{H}, \mathrm{m}) .{ }^{1} \mathrm{H}$ NMR $\left(\mathrm{CD}_{3} \mathrm{OD}, 400 \mathrm{MHz}\right) \delta 8.85(2 \mathrm{H}, \mathrm{d}, J 7.5 \mathrm{~Hz}) ; 7.62(2 \mathrm{H}, \mathrm{dd}, J 8.4,7.5 \mathrm{~Hz})$; 
$7.55(2 \mathrm{H}, \mathrm{dd}, J$ 8.4, $1.0 \mathrm{~Hz}) ; 3.50-3.46(4 \mathrm{H}, \mathrm{m}) ; 3.43(4 \mathrm{H}, \mathrm{t}, J 5.9 \mathrm{~Hz}) ; 3.27(4 \mathrm{H}, \mathrm{m}$, obscured by solvent resonance); $2.60-2.56(4 \mathrm{H}, \mathrm{m}) ; 1.94(4 \mathrm{H}$, quintet, J $5.9 \mathrm{~Hz}) ; 1.72-1.57(12 \mathrm{H}, \mathrm{m}) .{ }^{13} \mathrm{C} \mathrm{NMR}\left(\mathrm{CD}_{3} \mathrm{OD}, 100 \mathrm{MHz}\right)$ $\delta 170.18,167.17,151.28,144.80,131.94,128.48,128.17,122.02,121.28,117.59,98.27,55.13,49.42,39.48$, 33.67, 29.89, 27.46, 24.95, 20.45. MS (ES') $m / z 335$ (100\%, [M-H]').

1,7-Dicyanobenzo[1,2,3-de:4,5,6-d'e']diquinoline-2,8-diyl bis(trifluoromethanesulfonate) (9). A stirred mixture of the bis-DBU salt 8 ( $8.00 \mathrm{~g}, 12.5 \mathrm{mmol})$, pyridine $(4 \mathrm{~mL}, 3.91 \mathrm{~g}, 49.5 \mathrm{mmol})$, and dry acetonitrile (260 $\mathrm{mL})$ was cooled to $5{ }^{\circ} \mathrm{C}$ in an ice-water bath under nitrogen atmosphere. Triflic anhydride $(6 \mathrm{~mL}, 10.06 \mathrm{~g}$, $35.7 \mathrm{mmol}$ ) was added dropwise at such rate that the temperature of the reaction mixture did not exceed $7{ }^{\circ} \mathrm{C}$. The reaction mixture was warmed to room temperature and stirred under nitrogen atmosphere for $8 \mathrm{~h}$. The mixture was transferred to a one-necked flask and concentrated under reduced pressure using a rotary evaporator. Toluene $(60 \mathrm{~mL})$ and water $(120 \mathrm{~mL})$ were added and a precipitate was observed at the interface. The precipitate was filtered off and washed repeatedly with water then washed with a saturated, aqueous solution of $\mathrm{K}_{2} \mathrm{CO}_{3}$, then $\mathrm{AcOH}$ then water and toluene until washings consisted only of product (yellow, fluorescent color) which was monitored by TLC using DCM/light petroleum (bp 60-80 $\left.{ }^{\circ} \mathrm{C}\right)(67: 33$ ) system as an eluent. The washed solid was dried under vacuum, afforded the title compound 9 (6.6 g, 88\%) as a brownish yellow powder, $\mathrm{mp}$ decomposes above $290{ }^{\circ} \mathrm{C}$. (Found: $\mathrm{M}^{+\bullet}$ 599.9604. $\mathrm{C}_{22} \mathrm{H}_{6} \mathrm{~N}_{4} \mathrm{O}_{6} \mathrm{~S}_{2}$ requires: $\mathrm{M}^{+}$(599.9627). ${ }^{1} \mathrm{H} \mathrm{NMR}\left(\mathrm{CDCl}_{3}, 400 \mathrm{MHz}\right) \delta 9.66(2 \mathrm{H}, \mathrm{dd}, J \mathrm{f.8}, 0.9 \mathrm{~Hz}), 8.33(2 \mathrm{H}, \mathrm{dd}, J 8.4,0.9 \mathrm{~Hz}), 8.19(2 \mathrm{H}, \mathrm{dd}, J 8.4,7.8 \mathrm{~Hz})$. Insufficient solubility for ${ }^{13} \mathrm{C}$ NMR spectroscopic analysis. MS (EI) m/z 599.9 (100, $\mathrm{M}^{+*}$ ), 439 (23), 375 (35), 278 (35).

\section{1-Ethynyl-3-hexyloxybenzene (10b). ${ }^{32}$}

(a) 3-Hexyloxyphenylethynyltrimethylsilane: Potassium carbonate $(11.3 \mathrm{~g}, 81.8 \mathrm{mmol})$ was added with stirring to a solution of 3-iodophenol $(6.00 \mathrm{~g}, 27.3 \mathrm{mmol})$ in acetone $(50 \mathrm{~mL})$. 1-Bromohexane $(5.75 \mathrm{~mL}, 41.0 \mathrm{mmol})$ was added and the stirred solution was heated at reflux for $7 \mathrm{~h}$. The mixture was cooled and dilute hydrochloric acid $(1 \mathrm{M})$ was added. The whole was extracted with petroleum ether $(2 \times 50 \mathrm{~mL})$. The combined organic phase was washed sequentially with $\mathrm{H}_{2} \mathrm{O}(2 \times 100 \mathrm{~mL})$ and saturated brine $(100 \mathrm{~mL})$, then dried $\left(\mathrm{MgSO}_{4}\right)$. The solvent was evaporated under vacuum. The residue was dissolved in a small amount of light petroleum and filtered through a silica gel plug to afford 3-hexyloxy-1-iodobenzene (8.30 g, 99\%) as a clear oil. A solution of 3-hexyloxy-1-iodobenzene $(7.00 \mathrm{~g}, 23.0 \mathrm{mmol})$ and trimethylsilylacetylene $(16.3 \mathrm{~mL}, 115 \mathrm{mmol})$ in diethylamine $(100 \mathrm{~mL}$ ) was degassed by bubbling nitrogen through it for 30 minutes. Cuprous iodide (220 $\mathrm{mg}, 1.16 \mathrm{mmol}$ ) and tetrakistriphenylphospinepalladium(0) $(265 \mathrm{mg}, 0.229 \mathrm{mmol}$ ) were added and the mixture was stirred under nitrogen at room temperature for $4 \mathrm{~h}$. Water $(100 \mathrm{~mL})$ was added and the whole was extracted with DCM $(2 \times 100 \mathrm{~mL})$. The combined organic phase was washed with dilute hydrochloric acid (1M, $100 \mathrm{~mL})$, saturated $\mathrm{NaHCO}_{3}$ solution $(100 \mathrm{~mL}), \mathrm{H}_{2} \mathrm{O}(100 \mathrm{~mL})$ and saturated brine $(100 \mathrm{~mL})$, then dried $\left(\mathrm{MgSO}_{4}\right)$. The solvent was removed under vacuum and the residue was passed through a silica gel plug (DCM/light petroleum, 10:90) to give the title compound $(6.30 \mathrm{~g}, 99 \%)$ as a pale, yellow oil. ${ }^{1} \mathrm{H} \mathrm{NMR}(400 \mathrm{MHz}$, $\left.\mathrm{CDCl}_{3}\right) \delta 7.18(1 \mathrm{H}, \mathrm{t}, J 8.0 \mathrm{~Hz}), 7.03(1 \mathrm{H}, \mathrm{d}, J 7.6 \mathrm{~Hz}), 6.99-6.97(1 \mathrm{H}, \mathrm{m}), 6.86(1 \mathrm{H}, \mathrm{dd}, J 8.0,2.8 \mathrm{~Hz}), 3.94(2 \mathrm{H}, \mathrm{t}$, J $6.4 \mathrm{~Hz}), 1.80-1.72(2 \mathrm{H}, \mathrm{m}), 1.49-1.41(2 \mathrm{H}, \mathrm{m}), 1.37-1.31(4 \mathrm{H}, \mathrm{m}), 0.93-0.88(3 \mathrm{H}, \mathrm{m}), 0.25(9 \mathrm{H}, \mathrm{s})$.

(b) 1-Ethynyl-3-hexyloxybenzene: ${ }^{32} \mathrm{~K}_{2} \mathrm{CO}_{3}(11.9 \mathrm{~g}, 86.1 \mathrm{mmol})$ was added to a solution of 3-hexyloxyphenylethynyltrimethylsilane $(5.89 \mathrm{~g}, 21.5 \mathrm{mmol})$ in $\mathrm{MeOH}(100 \mathrm{~mL})$ and $\mathrm{H}_{2} \mathrm{O}(10 \mathrm{~mL})$ and the solution was stirred under nitrogen at $35^{\circ} \mathrm{C}$ for $6 \mathrm{~h}$. Dilute $\mathrm{HCl}(1 \mathrm{M}, 50 \mathrm{~mL})$ was added and the whole was extracted with light petroleum $(2 \times 100 \mathrm{~mL})$. The combined organic phase was washed with $\mathrm{H}_{2} \mathrm{O}(100 \mathrm{~mL})$, saturated brine (100 $\mathrm{mL})$, and dried $\left(\mathrm{MgSO}_{4}\right)$. The solvent was removed under vacuum and the residue was chromatographed over silica gel. Elution with $0-10 \% \mathrm{DCM}$ in light petroleum gave the title compound $10 \mathrm{~b}(3.44 \mathrm{~g}, 79 \%)$ as a pale, yellow oil. (Found: $\mathrm{M}^{+\bullet}$ 202.1352. $\mathrm{C}_{14} \mathrm{H}_{18} \mathrm{O}_{6}$ requires: $\mathrm{M}^{+\bullet}$ 202.1352). ${ }^{1} \mathrm{H} \mathrm{NMR}\left(400 \mathrm{MHz}, \mathrm{CDCl}_{3}\right) \delta 7.22(1 \mathrm{H}, \mathrm{dd}$, 
J 8.3, 7.6 Hz), $7.08(1 \mathrm{H}, \mathrm{dt}$, J 7.6, $1.2 \mathrm{~Hz}), 7.03(1 \mathrm{H}, \mathrm{dd}, J 2.6,1.4 \mathrm{~Hz}), 6.90(1 \mathrm{H}, \mathrm{ddd}, J$ 8.3, 2.6, $1.0 \mathrm{~Hz}), 3.94(2 \mathrm{H}$, $\mathrm{t}, J 6.6 \mathrm{~Hz}), 3.06(1 \mathrm{H}, \mathrm{s}), 1.81-1.75(2 \mathrm{H}, \mathrm{m}), 1.50-1.42(2 \mathrm{H}, \mathrm{m}), 1.40-1.32(4 \mathrm{H}, \mathrm{m}), 0.92(3 \mathrm{H}, \mathrm{t}, J 7.0 \mathrm{~Hz})$. These ${ }^{1} \mathrm{H}$ NMR data are consistent with the literature. ${ }^{32}{ }^{13} \mathrm{C} \mathrm{NMR}\left(\mathrm{CDCl}_{3}, 100 \mathrm{MHz}\right) \delta 158.88,129.37,124.45,123.03$, 117.62, 115.96, 83.68, 76.86, 68.08, 31.59, 29.18, 25.72, 22.63, 14.06. MS (EI) $m / z 202\left(24 \%, M^{+*}\right), 118(100)$. MS (APCI) m/z $203\left(100,[\mathrm{M}+\mathrm{H}]^{+}\right), 119(31)$.

\section{4-Ethynyl-1-hexyl-1H-pyrazole (10c).}

(a) 1-Hexyl-4-iodo-1H-pyrazole: Potassium hydroxide (4.7 g, $85.04 \mathrm{mmol})$ was added to a stirred solution of 4iodo- $1 \mathrm{H}$-pyrazole $(15.00 \mathrm{~g}, 77.3 \mathrm{mmol})$ in $\mathrm{EtOH}(60 \mathrm{~mL}) .1$-Bromohexane $(12.4 \mathrm{~mL}, 85.04 \mathrm{mmol})$ was added and the resulting mixture was stirred and heated to an internal temperature of $70{ }^{\circ} \mathrm{C}$ for $3 \mathrm{~h}$. The reaction mixture was cooled to room temperature and filtered through a bed of Celite. The filtrate was evaporated. The residue was diluted in DCM $(50 \mathrm{~mL})$. A white solid was filtered off and the filtrate was washed with $\mathrm{H}_{2} \mathrm{O}(4 \times 20 \mathrm{~mL})$, dried $\left(\mathrm{MgSO}_{4}\right)$, and evaporated to give the title compound $(14.27 \mathrm{~g}, 66 \%)$ as a clear yellow oil. ${ }^{1} \mathrm{H} \mathrm{NMR}(400$ $\left.\mathrm{MHz} \mathrm{CDCl}_{3}\right) \delta 7.49(1 \mathrm{H}, \mathrm{s}), 7.41(1 \mathrm{H}, \mathrm{s}), 4.10(2 \mathrm{H}, \mathrm{t}, J 7.2 \mathrm{~Hz}), 1.83(2 \mathrm{H}$, quin, $J 7.2 \mathrm{~Hz}), 1.34-1.23(6 \mathrm{H}, \mathrm{m}), 0.87$ $(3 \mathrm{H}, \mathrm{t}, J 6.7 \mathrm{~Hz})$.

(b) 1-Hexyl-4-[(trimethylsilyl)ethynyl]-1H-pyrazole: A solution of 1-hexyl-4-iodo-1H-pyrazole (13.07 g, 46.99 $\mathrm{mmol}$ ) and trimethylsilylacetylene $(33.2 \mathrm{~mL}, 234.95 \mathrm{mmol})$ in diethylamine $(200 \mathrm{~mL})$ was degassed by bubbling nitrogen through it for 30 minutes. Cuprous iodide $(0.45 \mathrm{~g}, 2.36 \mathrm{mmol})$ and tetrakis-triphenylphospinepalladium(0) $(0.54 \mathrm{~g}, 0.46 \mathrm{mmol})$ were then added and the solution was stirred under nitrogen at room temperature for $5 \mathrm{~h}$. Water $(200 \mathrm{~mL})$ was added and the whole was extracted with diethyl ether $(2 \times 200 \mathrm{~mL})$. The combined organic phase was washed sequentially with $1 \mathrm{M} \mathrm{HCl}$ solution $(2 \times 200 \mathrm{~mL})$, saturated $\mathrm{NaHCO}_{3}$ solution $(200 \mathrm{~mL}), \mathrm{H}_{2} \mathrm{O}(2 \times 200 \mathrm{~mL})$, and saturated brine $(200 \mathrm{~mL})$, then dried $\left(\mathrm{MgSO}_{4}\right)$. The solvent was removed under vacuum and the residue was passed through a silica gel plug using $3 \times 200 \mathrm{~mL}$ of DCM/light petroleum (30:70) and $1 \times 200 \mathrm{~mL}$ of DCM/light petroleum (50:50), to give the title compound (8.39 g, 72\%) as a light brown oil. ${ }^{1} \mathrm{H}$ NMR $\left(400 \mathrm{MHz}, \mathrm{CDCl}_{3}\right) \delta 7.59(1 \mathrm{H}, \mathrm{s}), 7.51(1 \mathrm{H}, \mathrm{s}), 4.06(2 \mathrm{H}, \mathrm{t}, J 7.1 \mathrm{~Hz}), 1.82(2 \mathrm{H}$, quin, J $7.2 \mathrm{~Hz}), 1.32-1.24(6 \mathrm{H}, \mathrm{m}), 0.87(3 \mathrm{H}, \mathrm{t}, J 6.9 \mathrm{~Hz}), 0.22(9 \mathrm{H}, \mathrm{s})$.

(c) 4-Ethynyl-1-hexyl-1H-pyrazole: $\mathrm{K}_{2} \mathrm{CO}_{3}(18.4 \mathrm{~g}, 133.15 \mathrm{mmol})$ was added to a stirred solution of 1-hexyl-4[(trimethylsilyl)ethynyl]-1H-pyrazole $(8.25 \mathrm{~g}, 33.25 \mathrm{mmol})$ in $\mathrm{MeOH}(155 \mathrm{~mL})$ and $\mathrm{H}_{2} \mathrm{O}(15.5 \mathrm{~mL})$. The resulting mixture was stirred under nitrogen at $35^{\circ} \mathrm{C}$ for $6 \mathrm{~h}$. Dilute $\mathrm{HCl}(1 \mathrm{M}, 77 \mathrm{~mL})$ was added and the whole was extracted with light petroleum $(2 \times 160 \mathrm{~mL})$. The combined organic phase was washed with $\mathrm{H}_{2} \mathrm{O}(160 \mathrm{~mL})$ and saturated brine $(160 \mathrm{~mL})$, then dried $\left(\mathrm{MgSO}_{4}\right)$. Removal of solvent under vacuum gave the title compound $10 \mathrm{c}(4.77 \mathrm{~g}, 81 \%)$ as a pale, orange oil. (Found: $\mathrm{M}^{+\bullet}$ 176.1309. $\mathrm{C}_{11} \mathrm{H}_{16} \mathrm{~N}_{2}$ requires: $\left.\mathrm{M}^{+\bullet} 176.1308\right) .{ }^{1} \mathrm{H} \mathrm{NMR}(400$ $\left.\mathrm{MHz}, \mathrm{CDCl}_{3}\right) \delta 7.60(1 \mathrm{H}, \mathrm{s}), 7.53(1 \mathrm{H}, \mathrm{s}), 4.08(2 \mathrm{H}, \mathrm{t}, J 7.2 \mathrm{~Hz}), 3.00(1 \mathrm{H}, \mathrm{s}), 1.84(2 \mathrm{H}$, quin, J 7.2 Hz), 1.33-1.24 $(6 \mathrm{H}, \mathrm{m}), 0.88(3 \mathrm{H}, \mathrm{t}, J 6.9 \mathrm{~Hz}) .{ }^{13} \mathrm{C} \mathrm{NMR}\left(\mathrm{CDCl}_{3}, 100 \mathrm{MHz}\right) \delta 142.16,132.38,101.64,78.00,75.34,52.44,31.22$, 30.11, 26.13, 22.43, 13.94. MS (EI) $\mathrm{m} / z 176\left(52 \%, \mathrm{M}^{+*}\right), 147$ (25), 105 (100). MS (APCI) m/z $177\left(100,[\mathrm{M}+\mathrm{H}]^{+}\right)$.

1-Ethynyl-1-(hexyloxy)cyclohexane (10d). Prepared by adapting the procedure of Padwa et al. ${ }^{33}$ Thus, a suspension of freshly pulverized potassium hydroxide $(38.32 \mathrm{~g}, 0.96 \mathrm{~mol})$ in DMSO (300 $\mathrm{mL})$ was stirred at 20 ${ }^{\circ} \mathrm{C}$ for 20 minutes. 1-Ethynylcyclohexanol $(17.88 \mathrm{~g}, 144 \mathrm{mmol})$ was added, followed by the addition of 1-bromohexane $(22.25 \mathrm{~mL}, 158 \mathrm{mmol})$. After the initial mild exotherm subsided, the mixture was stirred at $20^{\circ} \mathrm{C}$ for $18 \mathrm{~h}$. Water $(400 \mathrm{~mL})$ was added and the whole was extracted with $\mathrm{DCM}(1 \times 800 \mathrm{~mL}, 1 \times 400 \mathrm{~mL})$. The combined organic phase was washed with water $(3 \times 600 \mathrm{~mL})$ and dried $\left(\mathrm{MgSO}_{4}\right)$. Removal of the solvent under reduced pressure afforded a clear, pale yellow oil which was distilled under reduced pressure, affording the title compound $10 \mathrm{~d}(19.78 \mathrm{~g}, 66 \%)$ as a clear, colorless liquid, bp $60-63{ }^{\circ} \mathrm{C} / 0.05 \mathrm{mmHg}$. (Found: $\mathrm{M}^{+}$. 208.1830. $\mathrm{C}_{14} \mathrm{H}_{24} \mathrm{O}$ requires: $\mathrm{M}^{+\bullet}$ 208.1822). ${ }^{1} \mathrm{H} \mathrm{NMR}\left(\mathrm{CDCl}_{3}, 400 \mathrm{MHz}\right) \delta 3.53(2 \mathrm{H}, \mathrm{t}, J 6.7 \mathrm{~Hz}), 2.41(1 \mathrm{H}, \mathrm{s}$, $\mathrm{C} \equiv \mathrm{CH}), 1.92-1.83(2 \mathrm{H}, \mathrm{m}), 1.68-1.44(8 \mathrm{H}, \mathrm{m}), 1.39-1.23(8 \mathrm{H}, \mathrm{m}), 0.88(3 \mathrm{H}, \mathrm{t}, \mathrm{J}, 6.7 \mathrm{~Hz}) .{ }^{13} \mathrm{C} \mathrm{NMR}\left(\mathrm{CDCl}_{3}, 100 \mathrm{MHz}\right)$ 
$\delta 85.73,73.13,73.02,63.08,37.11,31.74,30.21,25.94,25.46,22.63(\times 2), 14.06 . \mathrm{MS}(\mathrm{EI}) \mathrm{m} / \mathrm{z} 208\left(11 \%, \mathrm{M}^{+*}\right)$, 193 (24), 165 (31), 125 (40), 81 (100). MS (APCI) m/z 209 (67, [M+H]+), 125 (38), 107 (100).

2,8-Bis[(triisopropylsilyl)ethynyl]benzo[1,2,3-de:4,5,6-d'e']diquinoline-1,7-dicarbonitrile (11a). Cuprous iodide (30 mg, $0.157 \mathrm{mmol}$ ) and bis(triphenylphosphine)palladium(II) dichloride (30 mg, $0.0427 \mathrm{mmol}$ ) were added to a stirred solution of the bis-triflate $9(0.20 \mathrm{~g}, 0.333 \mathrm{mmol})$ in dry THF $(3 \mathrm{~mL})$ under a nitrogen atmosphere. Triethylamine $(0.50 \mathrm{~mL}, 363 \mathrm{mg}, 3.59 \mathrm{mmol})$ was added and a solution of TIPSacetylene $10 \mathrm{a}(0.4 \mathrm{~mL}, 1.61 \mathrm{mmol})$ in dry THF $(2 \mathrm{~mL})$ was added dropwise over 20 minutes. The reaction mixture was stirred under gentle nitrogen flow at room temperature overnight. The volatiles were removed under reduced pressure. $\mathrm{CHCl}_{3}(30 \mathrm{~mL})$ was added to the residue and the organic phase was washed with water $(3 \times 15 \mathrm{~mL})$. The combined water phase was extracted with $\mathrm{CHCl}_{3}$ and the combined organic phase was dried $\left(\mathrm{MgSO}_{4}\right)$ and evaporated under reduced pressure. The residue was chromatographed over silica gel (DCM/light petroleum, 67:33) to give the title compound 11a (124 mg, 56\%) as a yellow powder, mp 293.5$294.5{ }^{\circ} \mathrm{C}$. (Found: C 75.90\%, H 7.31\%, N 8.45\%; $\mathrm{M}^{+\bullet}$ 664.3380. $\mathrm{C}_{42} \mathrm{H}_{48} \mathrm{~N}_{4} \mathrm{Si}_{2}$ requires: C 75.85\%, $\mathrm{H} 7.28 \%$, $\left.\mathrm{N} 8.42 \% ; \mathrm{M}^{+} \cdot 664.3412\right) .{ }^{1} \mathrm{H} \mathrm{NMR}\left(\mathrm{CDCl}_{3}, 400 \mathrm{MHz}\right) \delta 9.53(2 \mathrm{H}, \mathrm{dd}, J 7.8,0.8 \mathrm{~Hz}), 8.28(2 \mathrm{H}, \mathrm{dd}, J 8.4,0.8 \mathrm{~Hz})$, $8.01(2 \mathrm{H}, \mathrm{dd}, J$ 8.4, $7.8 \mathrm{~Hz}), 1.42-1.05(42 \mathrm{H}, \mathrm{m}) .{ }^{13} \mathrm{C} \mathrm{NMR}\left(\mathrm{CDCl}_{3}, 100 \mathrm{MHz}\right) \delta$ 148.70, 146.32, 140.73, 134.09, 132.67, 128.99, 126.16, 121.66, 118.31, 104.34, 102.48, 101.27, 18.80, 11.42. MS (EI) m/z 664 (100, $\left.\mathrm{M}^{+*}\right)$. UVvis $\left[\mathrm{CHCl}_{3}, \lambda_{\max }, \mathrm{nm}\right.$ (rel. int.)]: 284 (1.00), 392 (0.19), $406(0.19), 431(0.27), 457(0.40)$.

2,8-Bis\{[3-(hexyloxyl)phenyl]ethynyl\}benzo[1,2,3-de:4,5,6-d'e']diquinoline-1,7-dicarbonitrile (11b). Prepared by employing 1-ethynyl-3-(hexyloxy)benzene $\mathbf{1 0 b}^{32}$ in the procedure described for compound 11a. Elution with DCM gave the title compound $11 \mathrm{~b}(118 \mathrm{mg}, 50 \%)$ as a yellow powder, $\mathrm{mp} 246-247^{\circ} \mathrm{C}$. (Found: $\mathrm{M}^{+}$( 704.3177. $\mathrm{C}_{48} \mathrm{H}_{40} \mathrm{~N}_{4} \mathrm{O}_{2}$ requires: $\mathrm{M}^{+\bullet}$ 704.3146). ${ }^{1} \mathrm{H} \mathrm{NMR}\left(\mathrm{CDCl}_{3}, 400 \mathrm{MHz}\right) \delta 9.59(2 \mathrm{H}, \mathrm{dd}, J 7.8,0.8 \mathrm{~Hz}), 8.34$ $(2 \mathrm{H}, \mathrm{dd}, J$ 8.4, $0.8 \mathrm{~Hz}), 8.10(2 \mathrm{H}, \mathrm{dd}, J$ 8.4, 7.8 Hz), 7.40-7.38 $(2 \mathrm{H}, \mathrm{m}), 7.35-7.31(4 \mathrm{H}, \mathrm{m}), 7.04-7.01(2 \mathrm{H}, \mathrm{m}), 4.01$ $(4 \mathrm{H}, \mathrm{t}, J 6.5 \mathrm{~Hz}), 1.85-1.78(4 \mathrm{H}, \mathrm{m}), 1.53-1.45(4 \mathrm{H}, \mathrm{m}), 1.39-1.34(8 \mathrm{H}, \mathrm{m}), 0.93(6 \mathrm{H}, \mathrm{t}, J 7.0 \mathrm{~Hz})$. ${ }^{13} \mathrm{C} \mathrm{NMR}\left(\mathrm{CDCl}_{3}, 100 \mathrm{MHz}\right) \delta 159.23,148.98,146.79,141.05,134.16,133.07,129.92,129.05,126.49,125.40$, $121.98,121.78,118.50,118.06,117.93,104.35,96.94,86.35,68.45,31.80,29.37,25.93,22.84,14.28 . M S(E I)$ $\mathrm{m} / \mathrm{z} 704\left(47 \%, \mathrm{M}^{+\cdot}\right), 620$ (15), 536 (100), 507 (22). UV-vis [ $\mathrm{CHCl}_{3}, \lambda_{\max }, \mathrm{nm}$ (rel. int.)]: 295 (1.00), 3190.95$), 412$ (0.42), $434(0.35), 463(0.36)$.

2,8-Bis[(1-hexyl-1H-pyrazol-4-yl)ethynyl]benzo[1,2,3-de:4,5,6-d'e']diquinoline-1,7-dicarbonitrile (11c).

Prepared by employing 4-ethynyl-1-hexyl-1H-pyrazole 10c in the procedure described for 11a. Elution with $0-20 \%$ ethyl acetate in DCM afforded the title compound $11 \mathrm{c}(82 \mathrm{mg}, 38 \%)$ as a yellow powder, $\mathrm{mp} \sim 300{ }^{\circ} \mathrm{C}$ decomp to black (gradual degradation $>170{ }^{\circ} \mathrm{C}$ ). (Found: $\mathrm{M}^{+\bullet} 652.3073$. $\mathrm{C}_{42} \mathrm{H}_{36} \mathrm{~N}_{8}$ requires: $\mathrm{M}^{+\bullet}$ 652.3057). ${ }^{1} \mathrm{H} \mathrm{NMR}\left(\mathrm{CDCl}_{3}, 400 \mathrm{MHz}\right) \delta 9.54(2 \mathrm{H}, \mathrm{dd}, J 7.8,0.8 \mathrm{~Hz}), 8.29(2 \mathrm{H}, \mathrm{dd}, J 8.4,0.8 \mathrm{~Hz}), 8.07(2 \mathrm{H}, \mathrm{dd}, J 8.4,7.8 \mathrm{~Hz})$, $7.88(2 \mathrm{H}, \mathrm{s}), 7.83(2 \mathrm{H}, \mathrm{s}), 4.17(4 \mathrm{H}, \mathrm{t}, J 7.2 \mathrm{~Hz}), 1.94-1.88(4 \mathrm{H}, \mathrm{m}), 1.34-1.31(12 \mathrm{H}, \mathrm{m}), 0.90(6 \mathrm{H}, \mathrm{t}, J 6.8 \mathrm{~Hz})$. ${ }^{13} \mathrm{CNMR}\left(\mathrm{CDCl}_{3}, 125 \mathrm{MHz}\right) \delta 148.97,147.11,143.18,141.03,133.98,133.89,133.00,128.73,126.48,121.56$, 118.53, 103.70, 101.07, 89.87, 88.20, 53.00, 31.47, 30.32, 26.40, 22.69, 14.20. MS (EI) m/z 652 (95, $\left.\mathrm{M}^{+\cdot}\right), 623$ (23), 581 (100), 497 (34), 484 (28). UV-vis [ $\mathrm{CHCl}_{3}, \lambda_{\max }, \mathrm{nm}$ (rel. int.)]: 292 (0.81), 318 (1.00), 346 (0.71), 414 (0.50), 468 (0.27).

\section{2,8-Bis\{[(1-hexyloxy)cyclohexyl]ethynyl\}benzo[1,2,3-de:4,5,6-d'e']diquinoline-1,7-dicarbonitrile (11d).}

Prepared by employing 1-ethynyl-1-(hexyloxy)cyclohexane 10d in the procedure described for 11a. Elution with 33-100\% DCM in light petroleum, followed by recrystallization from ethyl acetate/light petroleum (bp 60-80 ${ }^{\circ} \mathrm{C}$ ), gave the title compound $11 \mathrm{~d}$ as small, yellow needles (104 mg, 44\%), mp 162-164 ${ }^{\circ} \mathrm{C}$. (Found: $\mathrm{M}^{+\bullet}$ 716.4053. $\mathrm{C}_{48} \mathrm{H}_{52} \mathrm{~N}_{4} \mathrm{O}_{2}$ requires: $\left.\mathrm{M}^{+\bullet} 716.4085\right) .{ }^{1} \mathrm{H} \mathrm{NMR}\left(\mathrm{CDCl}_{3}, 400 \mathrm{MHz}\right) \delta 9.54(2 \mathrm{H}, \mathrm{dd}, J 7.7,0.8 \mathrm{~Hz})$, $8.30(2 \mathrm{H}, \mathrm{dd}, J 8.4,0.8 \mathrm{~Hz}), 8.05(2 \mathrm{H}, \mathrm{dd}, J 8.4,7.7 \mathrm{~Hz}), 3.77(4 \mathrm{H}, \mathrm{t}, J 6.6 \mathrm{~Hz}), 2.20-2.10(4 \mathrm{H}, \mathrm{m}), 1.90-1.80(4 \mathrm{H}$, $\mathrm{m}), 1.80-1.70(8 \mathrm{H}, \mathrm{m}), 1.70-1.57(6 \mathrm{H}, \mathrm{m}), 1.48-1.38(6 \mathrm{H}, \mathrm{m}), 1.37-1.27(8 \mathrm{H}, \mathrm{m}), 0.91-0.85(6 \mathrm{H}, \mathrm{m})$. 
${ }^{13} \mathrm{C} \mathrm{NMR}\left(\mathrm{CDCl}_{3}, 100 \mathrm{MHz}\right) \delta 148.63,146.35,140.74,133.91,132.64,128.79,126.12,121.55,118.27,104.08$, $99.33,82.51,73.69,63.90,36.76,31.76,30.26,25.94,25.42,22.63,22.56,14.07 . \mathrm{MS}$ (EI) $\mathrm{m} / \mathrm{z} 716\left(100, \mathrm{M}^{+*}\right)$, 631 (77), 616 (80), 589 (53). UV-vis $\left[\mathrm{CHCl}_{3}, \lambda_{\max }, \mathrm{nm}\right.$ (rel. int.)]: 277 (1.00), 290 (0.76), 390 (0.20), 403 (0.20), 431 (0.30), $457(0.44)$.

2,8-Bis(5-hexylthien-2-yl)benzo[1,2,3-de:4,5,6-d'e']diquinoline-1,7-dicarbonitrile (12). Lithium chloride (85 $\mathrm{mg}, 2.00 \mathrm{mmol}$ ) and tetrakis(triphenylphosphine)palladium(0) $(30 \mathrm{mg}, 0.026 \mathrm{mmol}$ ) were added to a stirred suspension of the bis-triflate $9(0.20 \mathrm{~g}, 0.333 \mathrm{mmol})$ in dioxane $(5 \mathrm{~mL})$ under nitrogen atmosphere. 2-(Tributylstannyl)-5-hexylthiophene ${ }^{34,35}(0.35 \mathrm{~mL}, 609 \mathrm{mg}, 1.33 \mathrm{mmol})$ and a few crystals of 2,6-di-tert-butyl4-methylphenol were added. The reaction was stirred and heated at reflux under nitrogen for $4 \mathrm{~h}$. The mixture was cooled and a solution of KF $(530 \mathrm{mg})$ in water $(10 \mathrm{~mL})$ was added. The resulting mixture was stirred for 40 minutes. Chloroform $(10 \mathrm{~mL})$ was added and the whole mixture was filtered through a pad of Celite upon glass fiber filter paper. The organic phase of the filtrate was washed thrice with water, dried $\left(\mathrm{MgSO}_{4}\right)$, and evaporated under reduced pressure. The residue was recrystallized from a petroleum spirit/diethyl ether/chloroform mixture and chromatographed over silica gel. Elution with chloroform gave the title compound 12 (98 mg, 46\%) as an orange powder, $\mathrm{mp} 259.7-261.2{ }^{\circ} \mathrm{C}$. (Found: $\mathrm{M}^{+\bullet} 636.2374 . \mathrm{C}_{40} \mathrm{H}_{36} \mathrm{~N}_{4} \mathrm{~S}_{2}$ requires: $\mathrm{M}^{+\bullet}$ 636.2376). ${ }^{1} \mathrm{H} N M R\left(\mathrm{CDCl}_{3}, 400 \mathrm{MHz}\right) \delta 9.42(2 \mathrm{H}, \mathrm{dd}, J 7.7,0.9 \mathrm{~Hz}), 8.24-8.22(4 \mathrm{H}, \mathrm{m}), 8.00(2 \mathrm{H}$, $\mathrm{dd}, J$ 8.3, $7.8 \mathrm{~Hz}), 6.94-6.91(2 \mathrm{H}, \mathrm{m}), 2.91(4 \mathrm{H}, \mathrm{t}, J 7.5 \mathrm{~Hz}), 1.82-1.74(4 \mathrm{H}, \mathrm{m}), 1.48-1.41(4 \mathrm{H}, \mathrm{m}), 1.38-1.33(8 \mathrm{H}$, $\mathrm{m}), 0.94-0.88(6 \mathrm{H}, \mathrm{m}) .{ }^{13} \mathrm{C} \mathrm{NMR}\left(\mathrm{CDCl}_{3}, 100 \mathrm{MHz}\right) \delta 154.19,152.94,148.54,143.08,139.11,133.60,132.65$, $130.80,128.54,126.63,126.13,121.51,120.38,97.46,31.80,31.71,30.66,29.08,22.81,14.32 . M S$ (EI) $\mathrm{m} / \mathrm{z} 636\left(100, \mathrm{M}^{+\cdot}\right), 565$ (94). UV-vis [ $\mathrm{CHCl}_{3}, \lambda_{\max }, \mathrm{nm}$ (rel. int.)]: 327 (1.00), 424 (0.70).

\section{X-Ray crystallography}

Representative crystals were covered in a viscous oil and mounted on a cryoloop and cooled to $173 \mathrm{~K}(3 \mathrm{c})$ or $123 \mathrm{~K}(5)$. Datasets were collected using a Nonius KAPPA (3c) or Bruker APEXII (5) CCD diffractometer with Мока radiation $(\delta 0.71073 \AA$ ). Data collection and processing, including multiscan absorption corrections utilized proprietary software COLLECT/DENZO 39 or Apex $2 .^{40}$ The structures were solved and refined by conventional methods using the SHELX-2018 software suite. ${ }^{41}$ Non-hydrogen atoms were refined with anisotropic thermal parameters and hydrogen atoms attached to carbon were placed in calculated positions.

\section{Crystallographic data}

CCDC 2101284 (3c) and CCDC 2101285 (5) contain the supplementary crystallographic data for this paper. These data can be obtained free of charge from the Cambridge Crystallographic Data Centre via www.CCDC.cam.ac.uk/data_request/cif.

\section{Acknowledgements}

We thank Dr Roger Mulder and Dr Jo Cosgriff for assistance with NMR spectroscopy, and Mr Carl Braybrook and Dr Jo Cosgriff for mass spectrometry. We are grateful to Mr Peter Kemppinen for practical advice on the synthesis of building block 10b. We thank Dr Scott Courtney and Dr Michael Nairn (Boron Molecular Pty Ltd) for their generous gift of 4-iodo-1H-pyrazole and for useful advice on the synthesis of building block 10c. We also thank Dr Gavin Collis for the attempted preparations of bis-thienyl compound 12 via Suzuki reaction between bis-triflate 9 and 5-hexyl-2-thiopheneboronic acid pinacol ester. We are grateful to Dr Melissa Skidmore for the DSC and TGA analyses and Dr Scott Watkins for cyclic voltammetry and spin-coated film studies with $\mathbf{3 c}$. 


\section{Supplementary Material}

${ }^{1} \mathrm{H}$ and ${ }^{13} \mathrm{C}$ NMR spectra for compounds 3b, 3c, 3d, 5, 6, 8, 10b, 10c, 10d, 11a, 11b, 11c, 11d, 12; ${ }^{1} \mathrm{H} N M R$ spectrum for intermediate 9; HPLC chromatograms for compounds 3b, 3c, 3d, 5, 6, 8, 9, 11a, 11b, 11c, 11d, 12; DSC curves for compounds 3b, 3c, 5; TGA traces for compounds 3b, 3c; spin-coated film studies and associated UV-Vis spectra for compound 3c, and cyclic voltammogram for compound $\mathbf{3 d}$ are presented in the Supplementary Material file associated with this article.

\section{References}

1. Lin, Y.; Li, Y.; Zhan, X. Chem. Soc. Rev. 2012, 41, 4245-4272.

https://doi.org/10.1039/c2cs15313k

2. Dou, L.; Liu, Y.; Hong, Z.; Li, G.; Yang, Y. Chem. Rev. 2015, 115, 12633-12665.

https://doi.org/10.1021/acs.chemrev.5b00165

3. Mazzio, K. A.; Luscombe, C. K. Chem. Soc. Rev. 2015, 44, 78-90.

https://doi.org/10.1039/c4cs00227j

4. Walker, B.; Kim, C.; Nguyen, T.-Q. Chem. Mater. 2011, 23, 470-482.

https://doi.org/10.1021/cm102189g

5. Anthony, J. E.; Facchetti, A.; Heeney, M.; Marder, S. R.; Zhan, X. Adv. Mater. 2010, 22, 3876-3892. https://doi.org/10.1002/adma.200903628

6. Anthony, J. E. Chem. Mater. 2011, 23, 583-590.

https://doi.org/10.1021/cm1023019

7. Tatke, D. R.; Seshadri, S. Indian J. Chem. 1983, 22B, 1197-1199.

8. Tatke, D. R.; Seshadri, S. Dyes Pigm. 1986, 7, 153-158.

https://doi.org/10.1016/0143-7208(86)85005-7

9. He, B.; Pun, A. B.; Klivansky, L. M.; McGough, A. M.; Ye, Y.; Zhu, J.; Guo, J.; Teat, S. J.; Liu, Y. Chem. Mater. 2014, 26, 3920-3927.

https://doi.org/10.1021/cm5018272

10. He, B.; Dai, J.; Zherebetskyy, D.; Chen, T. L.; Zhang, B. A.; Teat, S. J.; Zhang, Q.; Wang, L.; Liu, Y. Chem. Sci. 2015, 6, 3180-3186.

https://doi.org/10.1039/c5sc00304k

11. Schneider, J. A.; Perepichka, D. F. J. Mater. Chem. C 2016, 4, 7269-7276.

https://doi.org/10.1039/c6tc02046a

12. Sarkar, P.; Jeon, I.-R.; Durola, F.; Bock, H. New J. Chem. 2012, 36, 570-574.

https://doi.org/10.1039/c2nj21033a

13. Bienewald, F.; Schmidhalter, B.; Berens, U.; Kirner, H. J. PCT Int. Appl. WO 2006/120143, PCT/EP2006/062007, 2006.

14. Cossey, A. L.; Harris, R. L. N.; Huppatz, J. L.; Phillips, J. N. Aust. J. Chem. 1976, 29, 1039-1050. https://doi.org/10.1071/CH9761039

15. Osdene, T. S.; Santilli, A. A.; McCardle, L. E.; Rosenthale, M. E. J. Med. Chem. 1967, 10, 165-171. https://doi.org/10.1021/jm00314a008

16. Whitehead, C. W.; Traverso, J. J. J. Am. Chem. Soc. 1955, 77, 5867-5872. 
17. Wang, K.; Nguyen, K.; Huang, Y.; Dömling, A. J. Comb. Chem. 2009, 11, 920-927. https://doi.org/10.1021/cc9000778

18. Ebata, H.; Izawa, T.; Miyazaki, E.; Takimiya, K.; Ikeda, M.; Kuwabara, H.; Yui, T. J. Am. Chem. Soc. 2007, 129, $15732-15733$.

https://doi.org/10.1021/ja074841i

19. Subramanian, S.; Park, S. K.; Parkin, S. R.; Podzorov, V.; Jackson, T. N.; Anthony, J. E. J. Am. Chem. Soc. 2008, 130, 2706-2707. https://doi.org/10.1021/ja073235k

20. Llorente, G. R.; Dufourg-Madec, M.-B.; Crouch, D. J.; Pritchard, R. G.; Ogierc, S.; Yeates, S. G. Chem. Commun. 2009, 3059-3061. https://doi.org/10.1039/b901448a

21. Bown, M.; Dunn, C. J.; Forsyth, C. M.; Kemppinen, P.; Singh, Th. B.; Skidmore, M. A.; Winzenberg, K. N. Aust. J. Chem. 2012, 65, 145-152.

http://dx.doi.org/10.1071/CH11375

22. Bose, D. S.; Idrees, M.; Jakka, N. M.; Rao, J. V. J. Comb. Chem. 2010, 12, 100-110. https://doi.org/10.1021/cc900129t

23. Ryabukhin, S. V.; Volochnyuk, D. M.; Plaskon, A. S.; Naumchik, V. S.; Tolmachev, A. A. Synthesis 2007, 1214-1224.

https://doi.org/10.1055/s-2007-966003

24. Strekowski, L.; Czarny, A.; Lee, H. J. Fluorine Chem. 2000, 104, 281-284. https://doi.org/10.1016/S0022-1139(00)00252-9

25. Smirnova, O. B.; Golovko, T. V.; Alekseeva, L. M.; Shashkov, A. S.; Granik, V. G. Russ. Chem. Bull. 2008, 57, 2410-2417. https://doi.org/10.1007/s11172-008-0344-9

26. Suloeva, E.; Yure, M.; Gudriniece, E.; Petrova, M.; Gutcaits, A. Chem. Heterocycl. Cmpds 2001, 37, 872-875. https://doi.org/10.1023/A:1012455709358

27. Troschtitz, R.; Zink, M.; Gnibl, R. J. Heterocycl. Chem. 1999, 36, 703-706. https://doi.org/10.1002/jhet.5570360321

28. Chinchilla, R.; Nájera, C. Chem. Soc. Rev. 2011, 40, 5084-5121. https://doi.org/10.1039/c1cs15071e

29. Panda, B.; Sarkar, T. K. Synthesis 2013, 45, 817-829. https://doi.org/10.1055/s-0032-1318119

30. Capani, J. S. Jr.; Chochran, J. E.; Liang, J. J. Org. Chem. 2019, 84, 9378-9384. https://doi.org/10.1021/acs.joc.9b01307

31. Winzenberg, K. N.; Kemppinen, P.; Fanchini, G.; Bown, M.; Collis, G. E.; Forsyth, C. M.; Hegedus, K.; Singh, Th. B.; Watkins, S. E. Chem. Mater. 2009, 21, 5701-5703. https://doi.org/10.1021/cm9028337

32. Pauls, H. W.; Sampson, P. B.; Forrest, B. T.; Laufer, R.; Liu, Y.; Feher, M.; Yao, Y.; Pan, G. PCT Int. Appl. WO 2008/109991, PCT/CA2008/000440, 2008.

33. Padwa, A.; Austin, D. J.; Gareau, Y.; Kassir, J. M.; Xu, S. L. J. Am. Chem. Soc. 1993, 115, 2637-2647. https://doi.org/10.1021/ja00060a012

34. Brusso, J. L.; Hirst, O. D.; Dadvand, A.; Ganesan, S.; Cicoira, F.; Robertson, C. M.; Oakley, R. T.; Rosei, F.; Perepichka, D. F. Chem. Mater. 2008, 20, 2484-2494. 
35. Jousselme, B.; Blanchard, P.; Gallego-Planas, N.; Levillain, E.; Delaunay, J.; Allain, M.; Richomme, P.;

Roncali, J. Chem. - Eur. J. 2003, 9, 5297-5306.

https://doi.org/10.1002/chem.200305010

36. Atmospheric Solids Analysis Probe $\left(A S A P^{\circledR}\right)$ Mass Spectrometry. Available online: http://www.asapms.com/ (accessed on 10 November 2021).

37. Petucci, C.; Diffendal, J. J. Mass Spectrom. 2008, 43, 1565-1568.

https://doi.org/10.1002/ims.1424

38. Ray, A.D.; Hammond, J.; Major, H. Eur. J. Mass Spectrom. 2010, 16, 169-174.

https://doi.org/10.1255/ejms.1069

39. COLLECT 1998 (Nonius BV, Delft, Netherlands); DENZO/SCALEPACK, Otwinowski, Z.; Minor, W. Methods in Enzymology, Vol. 276, Macromolecular Crystallography, Part A, edited by Carter, C. W. Jr \& Sweet, R. M. pp. 307-326. New York: Academic Press (1997).

40. Apex2 v. 2008.42008 (Bruker AXS: Madison, WI).

41. Sheldrick, G. M. Acta Crystallogr. Sect. C 2015, 71, 3-8.

https://doi.org/10.1107/S2053229614024218 